\title{
The association of insertions/deletions (INDELs) and variable number tandem repeats (VNTRs) with obesity and its related traits and complications
}

Yee-How Say (D)

\begin{abstract}
Background: Despite the fact that insertions/deletions (INDELs) are the second most common type of genetic variations and variable number tandem repeats (VNTRs) represent a large portion of the human genome, they have received far less attention than single nucleotide polymorphisms (SNPs) and larger forms of structural variation like copy number variations (CNVs), especially in genome-wide association studies (GWAS) of complex diseases like polygenic obesity. This is exemplified by the vast amount of review papers on the role of SNPs and CNVs in obesity, its related traits (like anthropometric measurements, biochemical variables, and eating behavior), and its related complications (like hypertension, hypertriglyceridemia, hypercholesterolemia, and insulin resistance-collectively known as metabolic syndrome). Hence, this paper reviews the types of INDELs and VNTRs that have been studied for association with obesity and its related traits and complications.

Main body of the abstract: These INDELs and VNTRs could be found in the obesity loci or genes from the earliest GWAS and candidate gene association studies, like FTO, genes in the leptin-proopiomelanocortin pathway, and UCP2/3. Given the important role of the brain serotonergic and dopaminergic reward system in obesity susceptibility, the association of INDELs and VNTRs in these neurotransmitters' metabolism and transport genes with obesity is also reviewed. Next, the role of INS VNTR in obesity and its related traits is questionable, since recent large-scale studies failed to replicate the earlier positive associations. As obesity results in chronic low-grade inflammation of the adipose tissue, the proinflammatory cytokine gene ILIRA and anti-inflammatory cytokine gene IL 4 have VNTRs that are implicated in obesity. A systemic proinflammatory state in combination with activation of the renin-angiotensin system and decreased nitric oxide bioavailability as found in obesity leads to endothelial dysfunction. This explains why VNTR and INDEL in eNOS and ACE, respectively, could be predisposing factors of obesity. Finally, two novel genes, DOCK5 and PER3, which are involved in the regulation of the Akt/MAPK pathway and circadian rhythm, respectively, have VNTRs and INDEL that might be associated with obesity.
\end{abstract}

Short conclusion: In conclusion, INDELs and VNTRs could have important functional consequences in the pathophysiology of obesity, and research on them should be continued to facilitate obesity prediction, prevention, and treatment.

Keywords: Indels, Variable number of tandem repeats, Genetic variation, Obesity, Anthropometric measurements

Correspondence: sayyh@utar.edu.my

Department of Biomedical Science, Faculty of Science, Universiti Tunku

Abdul Rahman (UTAR) Kampar Campus, Jalan Universiti, Bandar Barat, 31900

Kampar, Perak, Malaysia 


\section{Background}

\section{Obesity and its genetic factors}

The worldwide prevalence of overweight and obesity, which rose by $27.5 \%$ in adults and $47.1 \%$ in children between 1980 and 2013 [1], has been described as a global pandemic. Obesity, defined as abnormal or excessive fat accumulation that presents a risk to health, is associated with increased morbidity and mortality related to several conditions such as type 2 diabetes (T2D) and cardiovascular disease [2]. While obesity is mainly caused by environmental factors such as dietary habits and physical activity, it still has a strong genetic component. Family, twin, and adoption studies indicate that genetics account for $20-84 \%$ of population variation in body mass index (BMI) [3, 4], the most commonly used anthropometric measurement of adiposity apart from direct body fat content imaging techniques. Other anthropometric measurements such as waist circumference (WC) and waist-hip ratio (WHR) are more correlated with abdominal fat deposition (central adiposity) than BMI and are considered strong risk factors for T2D [5].

The study of genetic factors involved in body weight regulation in humans heavily extrapolated from studies on rodent monogenic obesity models in the 1990s. Monogenic obesity is a rare form of severe obesity that results from gene mutations that have large effect sizes. By screening children with severe, young-onset obesity for the genetic defects identified in mice, loss-offunction (LOF) mutations causing deficiencies are found in genes encoding for appetite-regulating hormones or their receptors such as leptin $(L E P)$ [6], leptin receptor $(L E P R)$ [7], proopiomelanocortin $(P O M C)$ [8], and melanocortin 4 receptor $(M C 4 R)$ [9]. As these LOF variants are only found in monogenic obesity, they are uncommon in the general population. Therefore, various genetic approaches like candidate gene association studies and genome-wide linkage studies have been performed to identify susceptibility genetic loci for common polygenic obesity instead in the early 2000s. However, these approaches have been met with little success as the genes or loci found to be associated with obesity vary heavily across ethnic populations and are therefore difficult to replicate due to several reasons as reviewed in [10].

Fortunately, after the completion of the Human Genome Project in 2003 [11] and the International HapMap Project (Phase I) in 2005 [12] in conjunction with the development of high-throughput genotyping techniques as well as bioinformatics and statistical methods, various obesity genome-wide association studies (GWAS) were conducted from 2006 [13]. In GWAS, thousands of genetic variants are genotyped on a single microarray technology for association with obesity and its related traits and complications [14]. In the recent decade, numerous GWAS among Caucasians (like the Genetic
Investigation of Anthropometric Traits (GIANT) consortium) [15], East Asians, and Africans, each analyzing $>50,000$ individual subjects, have identified $>90$ loci for obesity (reviewed in [16]).

\section{The potential of INDELs and VNTRs in obesity}

Genetic variations in the human genome present as (i) single nucleotide polymorphisms (SNPs), (ii) insertions/ deletions (INDELs) ranging from 1 to $10,000 \mathrm{bp}$ in length [17], and (iii) structural variations that account for a greater number of base pairs. An example of structural variation is variable number tandem repeat (VNTR), which is a DNA sequence motif that is repeated several times in the genome continuously and constitutes Mendelian inheritance (reviewed in $[18,19]$ ). VNTRs cover both microsatellites or short tandem repeat (STR) (1-6-bp-long motifs) [20] and minisatellites (hundreds of base pairs block motifs) [21, 22]. The number of times the sequence is repeated differs within and between individuals. The highly polymorphic nature of VNTRs makes them very informative as a class of markers to map for disease loci in family linkage studies [18].

SNPs are the most common type of genetic variations found in the human genome, and a substantial amount of research, such as that by the International HapMap Project, has been focused on accurately mapping and identifying them [23]. In spite of being the second most common type of genetic variations and constituting a large portion of the human genome [24], INDELs and VNTRs are more challenging to identify compared to SNPs, due to library preparation, sequencing biases, and algorithm artifact issues (reviewed in $[25,26]$ ). Due to the nature of INDELs and VNTRs, genotyping them on the array platforms that SNP genotyping utilizes has led to technical problems like complications in scoring the number of repeats present. Unlike the vast amount of reviews available in the literature on the association of SNPs and larger forms of structural variation like copy number variations (CNVs) with obesity and its related traits (like anthropometric measurements, biochemical variables, and eating behavior) and its related complications (like hypertension, hypertriglyceridemia, hypercholesterolemia, and insulin resistance-collectively known as metabolic syndrome), INDELs and VNTRs have received far less coverage and attention. In fact, INDELs and VNTRs could have important functional consequences by regulating gene transcription and messenger RNA (mRNA) translation or by modifying the structure of proteins. In addition, since INDELs and VNTRs have greater potential for mutations than SNPs, they may also have an important role to play in the evolution of specific higher organism traits, such as behavior [27]. Using examples from the literature, this review highlights the functional consequences of INDELs and 
VNTRs in the human genome and their association with obesity and related traits. With the advent of faster and cheaper next-generation genome and exome sequencing, paired with the rise of the software availability for genome-wide detection of INDELs (like indelMINER [28]) and VNTRs (like VNTRseek [29]), it is hoped that association and functional characterization studies between INDELs/VNTRs and obesity should be continued and not neglected.

\section{Main text \\ INDELs and VNTRs in obesity genes from the earliest GWAS and candidate gene studies}

Numerous INDELs and VNTRs are located around obesity-susceptible genes or loci identified by the earliest GWAS and candidate gene studies. These mainly include genes that are involved in energy balance, appetite regulation, and adipogenesis, i.e., fat mass and obesity-associated protein gene (FTO), and genes in the leptin-proopiomelanocortin pathway and uncoupling protein families. It is possible that the association between INDELs/VNTRs and obesity is affected by the obesity-related SNPs because of strong linkage disequilibrium, and the risk or protective variants of INDELs/VNTRs are linked to the counterparts of the focal SNPs.

\section{Fat mass and obesity-associated protein gene (FTO)}

Genetic variants of FTO were the first common genetic variants to be associated with increased obesity and BMI [30], with 89 genetic variants in introns 1 and 2 that have the strongest genome-wide association signal and are in high linkage disequilibrium in Europeans [30-32]. This association was replicated in several distinct ethnic populations (reviewed in [33]), making FTO the single strongest genetic factor of obesity. Most studies have focused on variants of a 42-kb haplotype block around the lead SNP rs9939609 in the first intron, and recently, a causal variant rs 142108 resulting in cellular phenotypes consistent with obesity, like increased triglyceride accumulation and decreased mitochondrial energy generation, has been identified [34]. FTO is a very large gene containing nine exons, spanning $412 \mathrm{~kb}$. However, only a few studies have identified obesity-associated SNPs in other regions of the gene, in introns 2, 3 [35], and 8 [36]. By using massive parallel sequencing to sequence the entire length of $F T O$, Sällman Almén et al. identified 13 insertions and 27 deletions that range between 1 and $9 \mathrm{bp}$, of which 16 overlap known INDELs in dbSNP and 24 are potential novel INDELs [37]. Three insertions (minor allele frequency $<5 \%$ ) reside within the obesityassociated haplotype of intron 1 . However, none of these INDELs contributed to obesity association [37].

\section{Leptin gene (LEP)}

The discovery that the mouse obesity phenotype $o b$ has been attributed to mutations in the mouse leptin gene [38], and that mutations in the human homolog $(L E P)$ cause early-onset monogenic obesity in humans [6, 39], has led to significant progress in understanding the etiology of obesity. Analysis of the leptin-proopiomelanocortin (LEP-POMC) pathway has revealed the role of the pathway in hypothalamic control of feeding behavior and energy balance [40, 41]. A GWAS which identified 14 known obesity susceptibility variants and 18 new loci that were associated with BMI found that some of these loci are mapped at the LEP-POMC pathway, i.e., LEP and its receptor $L E P R, P O M C$ and MC4R [42].

While mutations in LEP cause monogenic obesity, there have been numerous research in determining whether genetic variations in or near $L E P$ influences susceptibility to polygenic obesity. Using STR markers flanking the $L E P$ locus at human chromosome 7q31.332.1, several groups reported evidence of linkage and/or association between these STRs and obesity-related traits, albeit with inconsistencies [43-47]. A metaanalysis of the linkage data concluded that the evidence of a gene influencing obesity in the region of the LEP locus was extremely strong [48]. A tetranucleotide VNTR, (CTTT)n, was first identified at 3912 bp 3' of the LEP stop codon (476 bp 3' of the 3' UTR) [49]. Fifteen alleles were detected in this VNTR and were grouped into shorter class I alleles (121-145 bp) and longer class II alleles (197-225 bp); however, they were not significantly associated with obesity and T2D [49]. Nevertheless, the same group subsequently found a significant association between class I/class I genotype and hypertension, independent of obesity [50]. In another study among populations worldwide, Moffett et al. grouped this VNTR into three general classes-type 1 alleles (146-178 bp), type 2 alleles (165-193 bp), and type 3 alleles (210-254 bp), but they did not investigate the association with obesity or related traits [51]. In the Brazilian population, this VNTR was significantly associated with obesity-related traits and leptinemia, where the frequency of class I alleles was significantly higher in obese than in nonobese [52, 53]. The risk for obesity was two times higher in class I allele carriers; class I allele was associated with increased BMI and WC, and plasma leptin in women [52]. In combination with $L E P$ -2548GG SNP, LEP VNTR/SNP class I/G combined genotypes (I/IGG, I/IGA, and I/IIGG) were significantly associated with obesity and increased BMI, WC, leptin, and triglycerides in women [53]. However, Nauruan (Pacific Islander) men homozygous for class II allele, along with homozygosity in the two other LEPR Gln223Arg and PRO1019pro SNPs, had elevated insulin [54]. A long-base-pair allele (class II in [49])-allele 
226-of this VNTR was also associated with lower BMI in adult Samoans [55].

\section{Leptin receptor gene (LEPR)}

$L E P R$, located near the STR D1S200, has been associated with increased BMI and fat mass [56]. The LEPR D1S200 17 allele was associated with increased susceptibility to obesity and increased BMI, WC, and WHR in Brazilian individuals [57]. Other STRs flanking LEPR by approximately 9 and $3 \mathrm{cM}$, such as D1S3728 and D1S1665, were proposed to contribute to plasma leptin concentrations, adiposity, and body weight in individuals with dyslipidemia [58]. Two VNTRs located at introns 3, (CA) $n$, and 16, (CTTT) $n$, of LEPR were shown to be associated, respectively, with BMI and fat-free mass in the Quebec Family Study [59]. A common CTTTApentanucleotide 3' UTR INDEL in LEPR was associated with increased body weight in patients in the Finnish Diabetes Prevention Study [60], while another novel TAT-trinucleotide INDEL variant in the $1078 \mathrm{Y}$ codon of $L E P R$ (containing a putative phosphorylation site) was not associated with obesity in Dutch Caucasians [61].

\section{Proopiomelanocortin gene (POMC)}

A genome-wide scan found that D2S1788 GATAtetranucleotide VNTR near POMC had strong linkage with serum leptin levels and fat mass in Mexican Americans [62, 63]. This VNTR was also associated with plasma leptin levels in French [64], African-American [65], and Hispanic populations [66], but not in Brazilians [57]. This VNTR has also been associated with BMI in the Framingham Heart Study families [67]. However, this VNTR together with four others near POMC-D2S2170, D2S144, D2S1268, and D2S1348-showed no association with obesity in Samoans [55]. Out of three VNTRs (D2S2221, D2S171, D2S2337) screened for association with obesity and related traits in French Caucasian families, only D2S2337 had linkage with serum leptin levels [68]. Lastly, a cryptic trinucleotide repeat (9-bp) INDEL detected in exon 3 of POMC (codon 94) [69] was associated with elevated serum leptin levels in Swedish [70] and Danish [71] men. However, this INDEL was not associated with salivary cortisol [72], obesity, and related traits $[63,71]$.

\section{Melanocortin 4 receptor gene (MC4R)}

Like FTO, MC4R has been extensively studied in obesity research. To date, more than 160 mutations in $M C 4 R$, mostly heterozygous (codominant inheritance), were identified mainly in obese individuals, encompassing nonsynonymous, nonsense, deletion, and frameshift mutations. Therefore, MC4R is the most commonly known monogenic cause of human obesity (reviewed in [73, $74])$. In 1998, two groups reported the first functionally relevant $M C 4 R$ mutations for obesity $[75,76]$. Yeo et al. identified a hyperphagic individual who was heterozygous for a deletion of 4 bp at codon 211, resulting in a frameshift mutation which leads to a premature stop codon [75]. Another frameshift mutation (4-bp insertion after codon 244) was detected in a woman with earlyonset obesity, whose family members who carried the same mutation were obese whereas the noncarriers were not obese [76]. The first mutation analysis in 306 obese individuals further confirmed the role of $M C 4 R$ in obesity [77]. As the focus of this review is on common polygenic obesity, the examples of INDELs in MC4R which lead to rare monogenic obesity will not be further discussed here. The association of MC4R SNPs with polygenic obesity will also not be further discussed here. Nevertheless, recent GWAS have identified SNPs in the MC4R 3' UTR region to have a strong association with obesity, with rs17782313 showing the second strongest association signal after FTO [78] and rs129070134 showing association not just in Caucasian populations but also in Asian populations $[79,80]$.

Eight STRs flanking the MC4R gene-D18S851, D18S487, D18S69, D18S858, D18S849, D18S1155, D18S64, D18S38-have demonstrated linkage with obesity in Finnish sib pairs, with D18S849 showing the strongest linkage [81]. The D18S858 11/12 allele was also associated with increased BMI and WC in Brazilian subjects [57]. This locus was also found to be related to other obesity-related complications, like systolic BP (SBP) [82] and cancer [83].

\section{Uncoupling protein 2 and 3 genes (UCP2 and UCP3)}

Uncoupling proteins (UCPs) are mitochondrial transporters that mediate energy homeostasis and thermogenesis. Genetic variants in the UCP2/UCP3 cluster have been considered candidate markers for obesity, diabetes, and fat metabolism in humans [84]. D11S912 and other STRs flanking $U C P 2$ and $U C P 3$ showed some evidence of linkage with obesity and BMI $[4,81]$. The 43 allele of D11S912 STR was associated with increased risk for obesity in Brazilians [57], consistent with a genomewide linkage scan study in the Framingham Heart Study families [4]. Campbell et al. reported allelic association between D11S911 and anorexia nervosa (AN) and hypothesized that this may reflect differences in metabolic rate between patients with AN and controls [85]. However, other studies found that other STRs flanking $U C P 2-U C P 3$ are unlikely to have a substantial effect on the expression of obesity-related phenotypes in Mexican American [86] and Caucasian [87] populations.

A 45-bp INDEL variant in the 3' UTR of $U C P 2$ exon 8 (reviewed in [88]) has been variably associated with altered BMI, changes in energy expenditure, and maintenance of body weight after overfeeding [89, 90]. 
Previous studies showed that carriers of the I (insertion) allele had significantly higher risk of developing obesity and BMI compared to the D (deletion) allele [88, 91-94]. In our study, we found that this INDEL was associated with obesity and overall adiposity among females [95]. However, when adjusted for age and ethnicity, this association was abolished for obesity but remained significant for overall adiposity; those carrying the ID genotype or I allele had almost twofold risk of having higher overall adiposity and had higher total body fat (TBF) compared to the D allele [95]. Similarly, Yanowski et al. also found that TBF was significantly associated and greater in ID subjects compared to II subjects [96], while WHR was not significantly different in Caucasians, African-Americans, and Asians [96]. Also, no association between this INDEL and WC and waist-to-thigh ratio was found among Pima Indians [97].

\section{INDELs and VNTRs in serotonergic and dopaminergic system genes}

Given the important role of the brain serotonergic and dopaminergic reward system in weight gain and obesity susceptibility, investigation of the candidate genes of these neurotransmitters' metabolism and transport is a growing area of research $[98,99]$.

\section{5-Hydroxytryptamine (serotonin) transporter gene (SLC6A4/5HTT)}

The serotonin transporter protein (SERT or 5-HTT), which is encoded by $S L C 6 A 4$, recycles serotonin (5-HT) after an action potential and regulates the availability of serotonin at the synaptic cleft [100]. Since its description in 1993, SLC6A4 has been a candidate gene for a variety of neuropsychiatric conditions, given the importance of serotonergic function in mood and the widespread clinical use of selective serotonin reuptake inhibitors (SSRIs) as anxiolytics and antidepressants [100]. In addition to SNPs, two polymorphic regions influencing the transcription activity of $S L C 6 A 4$ have been studied extensively in search of association with a range of neuropsychiatric phenotypes (reviewed in [101]). The serotonin transporter-linked polymorphic region (5-HTTLPR) is located $1 \mathrm{~kb}$ upstream of the transcription start site and consists of a number of 20-23-bp repeat units varying from 13 to 22 units. Within the 5-HTTLPR, a 43-bp INDEL gives rise to the most common repeat elements $14 \mathrm{R}$ (short, S) and 16R (long, L) alleles [102]. The second 5-HTT polymorphic region is a multi-allelic 17-bp VNTR in intron 2 (named STin2) with two common alleles with 10 and 12 repeats and a rare allele with 9 repeats $[103,104]$.

A study with Argentinean children/adolescents demonstrated that individuals with the 5-HTTLPR S allele were found to be at greater risk of being overweight/ obese as result of a genetic predisposition that leads to higher food consumption [105]. Another study with young American adults obtained similar results, whereby the prevalence of obesity combined with overweight was significantly lower among L allele carriers compared with individuals homozygous for the $S$ allele [98]. In the same direction, Markus and Capello found that $\mathrm{S}$ allele carriers had significantly higher BMI than LS and LL carriers in highly neurotic individuals, indicating that cognitive stress vulnerabilities may be a mediator of the association between 5-HTTLPR and BMI [106]. In a further study by the same group, they found that SS homozygotes undergoing stress vulnerability tend to increase the appetite for sweets because sweet foods might have become more emotionally rewarding in these subjects [107]. Furthermore, Lan et al. described an age-dependent modification of 5-HTTLPR association with obesity development; they demonstrated that the SS genotype was associated with BMI and obesity in nonelderly patients with stroke but not in elderly patients [108]. Recently, it was found that Brazilian children with SS homozygotes also had higher anthropometric parameters (BMI Z-score, sum of skinfolds, and WC) and higher food intake at the assessments of the three stages in early childhood [109]. The $\mathrm{S}$ allele was also strongly associated with the presence of T2D in Greeks independent of obesity status [110], but no association with T2D and obesity was found in the Pakistani population [111].

On the other hand, Bah et al. showed different results [112]. They showed that SS tended to be more frequent in underweight subjects, and this association was significant only in Swedish men. However, there was no significant association between 5-HTTLPR and BMI [112]. Borkowska et al. detected association of the $\mathrm{S}$ allele with development of depressive temperament while the $\mathrm{L}$ allele was associated with greater obesity and prevalence of depression in Polish adults [113]. There was no significant association observed between 5-HTTLPR and BMI status in Turkish studies [114, 115].

The first study which investigated the association between STin2 VNTR and obesity found no significant effect on obesity in Turkish adults [115]. However, when combined with 5-HTTLPR, the L/10 allele haplotype showed a significant association with overweight/obesity in Portuguese adults [116]. Moreover, in inactive individuals, overweight/obesity was found nominally associated with the STin2 10 allele but significantly associated with the 5-HTTLPR L allele [116].

\section{Dopamine transporter gene (SLC6A3/DAT1)}

The dopamine transporter (DAT1), encoded by $S L C 6 A 3 /$ $D A T 1$, is a membrane-spanning protein which terminates the synaptic transmission of dopamine by reuptake into the presynaptic nerve terminals [117]. The human DAT1 contains a VNTR in its 3' UTR, consisting of 
repetitions of a 40-bp core sequence [118]. This VNTR varies between 3 and 13 repeats, of which the common 10-repeat (long; L) allele was associated with an increased expression of the transporter, leading to greater dopamine (DA) reuptake and lower synaptic levels of DA [119]. The 9-repeat (short; S) allele also has greater DA signaling in the reward circuitry than the L allele [119]. The likelihood of obesity in African-American smokers with the LL genotype was 5.16 times compared with the SS or SL genotypes [120]. This VNTR was also associated with future weight gain; $\mathrm{S}$ allele carriers showed greater increases in BMI than L allele carriers [121]. However, in a Turkish study, no effect of this VNTR on obesity was observed [115].

More literature reported on the association between this VNTR and eating behavior. It was found that there was an association between this VNTR and binge eating behavior [122], suggesting that dysregulation of dopamine reuptake may act as a common pathophysiological mechanism in eating disorders. It was found that smokers homozygous for the $\mathrm{L}$ allele and who had high food reinforcement levels consumed more energy than those with the $\mathrm{S}$ allele or who had low food reinforcement levels [123]. However, this finding could not be generalized to nonsmokers as the subjects were regular smokers. To circumvent this, a study conducted by the same group in a larger sample of nonsmokers did not find any significant association between this VNTR and energy intake or between VNTR and food reinforcement [124]. Results also supported the role of DAT1 in regulating appetitive response to methylphenidate, a psychomotor stimulant. Subjects with binge eating disorders with at least one $\mathrm{S}$ allele showed a significant suppression of appetite in response to methylphenidate, compared with controls with this allele or to subjects with the LL genotype [125].

\section{Dopamine receptor D2 gene (DRD2)}

Obese subjects, relative to lean ones, have reduced D2 receptors (DRD2) in the striatum [126], due to decreased metabolism in prefrontal cortical regions [127]. An inverse relationship between BMI and DRD2 has also been described; specifically, those individuals with the lowest DRD2 brain density had the largest BMI [126]. In a single study examining the association between DRD2$141 C$ INDEL and future weight gain, there was no association found between this INDEL and change in BMI over a 2-year follow-up [121]. Other studies tend to investigate the association of another genetic variant that modulates the density of DRD2-DRD2/ANKK1-TaqIA SNP - with both obesity [126] and addictive disorders $[128,129]$ instead, which is out of the scope of this review.

\section{Dopamine receptor $D 4$ gene (DRD4)}

Another gene encoding dopamine receptors is DRD4, which is highly expressed in the prefrontal cortex and other brain regions that are involved in the reward circuits that mediate the reinforcing properties of food, such as the amygdala, hippocampus, and hypothalamus $[130,131]$. This gene contains a highly polymorphic 48bp VNTR within exon 3, which is located in the third cytoplasmic loop of the receptor [132]. Nine alleles of this VNTR have been identified worldwide, with the number of repeats ranging from 2 to 10 ; 4-repeat (4R; S) and 7-repeat (7R; L) alleles are the most common [133]. This VNTR has been hypothesized to affect the transmitted signal in the postsynaptic neuron. Individuals with at least one $\geq 7 \mathrm{R}$ allele showed reduced binding affinities and receptor densities for dopamine neurotransmission [134]. This VNTR has also been associated with increased food intake in patients treated with DRD4related antipsychotics [135], and with addictive behaviors [136]. In some studies, DRD4 VNTR and higher BMI correlation was shown $[137,138]$. The $S$ allele was also associated with increases in BMI over a 2-year follow-up period [121].

DRD4 VNTR also influences BMI and body composition in the context of other environmental factors. For example, 7R allele/season-of-birth interactions increase the risk for obesity in women with either seasonal affective disorder [139] or bulimia nervosa [140]. A study of Kenyan Ariaal men found that BMI was higher in those with one or two $7 \mathrm{R}$ alleles in the nomadic population, but lower among the settled, due primarily to differences in fat-free body mass [141]. Children who carried the $7 \mathrm{R}$ allele also appeared to be more influenced by maternal sensitivity (response to a child's emotional signals) as it relates to overweight/obesity risk [142]. However, there was no association between this VNTR alleles with AN, underweight, or extreme early-onset obesity [143]. Similarly, no association was detected between alleles/genotypes and BMI, BMI-SDS, or skinfold thickness at baseline nor success in the weight loss intervention in obese German children [144]. Similarly, there was no association found with obesity in Turkish adults [115]. There was also no association found between level of physical activity and sedentary lifestyle in Polish adults [145].

\section{Monoamine oxidase A gene (MAOA)}

Monoamine oxidase (MAO) is an outer membrane mitochondrial enzyme that catalyzes the turnover of several catecholamine neurotransmitters, namely serotonin, noradrenaline, and dopamine [146]. MAOA, an isoenzyme of MAO, is encoded by $M A O A$ located on the short arm of the $\mathrm{X}$ chromosome between bands Xp11.23 and Xp11.4 [147]. It contains a 30-bp VNTR 
located at the promoter region, manifesting as six functional allele variants containing either 2-, 3-, 3.5-, 4-, 5-, or 6-repeat copies [146], with the 3- (3R) and 4-repeat (4R) alleles being the most common [148]. Certain alleles may confer lower transcriptional efficiency than others; the $3 \mathrm{R}$ allele conveys lower efficiency, the 3.5-repeat and $4 R$ alleles result in higher efficiency [146, 149], while to date, there is less consensus regarding the transcriptional efficiency of the other less commonly occurring alleles (i.e., 2-, 5-, and 6-repeat). The primary role of MAOA in regulating catecholamine turnover and hence ultimately influencing their levels indicates that its VNTR is a highly plausible candidate for affecting individual differences in physiological and psychological traits, such as obesity, personality traits, and alcoholism risk [150]. A previous study showed a significant association of MAOA VNTR alleles (either alone or with combination of other gene variants) with weight and BMI in Caucasian populations [98, 151-153], while our unpublished study showed association only with weight; both studies agree that subjects having the lower activity 3R allele tend to have a lower weight than the higher activity $4 \mathrm{R}$ allele. Meanwhile, another study showed a significant association of this VNTR with obesity in a mixedethnic American population [154], while Dias et al. [116] and our unpublished studies showed otherwise. In a previous study, Brazilian boys who carried the $4 \mathrm{R}$ allele were associated with higher intake of lipid- and sugardense foods [155]. The increased intake of lipid- and sugar-dense foods might have led to increased lipid accumulation in adipose tissues, leading to higher TBF and $\mathrm{SF}$ in $4 \mathrm{R}$ allele carriers, as shown in our unpublished study. However, a previous study showed that Portuguese men with the 3R3R genotype had significantly higher TBF [116].

\section{Tyrosine hydroxylase gene ( $\mathrm{TH})$}

Tyrosine hydroxylase $(\mathrm{TH})$ is a rate-limiting enzyme in adrenaline, noradrenaline, and dopamine synthesis, and its coding gene, $T H$, is located at chromosome $11 \mathrm{p} 15$ [156]. An extensively studied TH polymorphism known as $(\mathrm{TCAT})_{n}$ is a tetranucleotide VNTR located in the first intron of $\mathrm{TH}$, giving five alleles-T6, T7, T8, T9, and $\mathrm{T} 10$ [157]. The alternate splicing process of the $(\mathrm{TCAT})_{n}$ polymorphism involving the $3^{\prime}$ end of exon 1 and differential exclusion at exon 2 will produce an uneven regulatory effect due to the different combination of $(\mathrm{TCAT})_{n}$ repeats [158]. It has also been reported that the cerebrospinal fluid and serum concentrations of the metabolites in the dopaminergic pathway of humans have been altered by this VNTR $[159,160]$. Since TH is the rate-limiting enzyme for the biosynthesis of catecholamines, this VNTR has attracted considerable attention and is a candidate marker for various neuropsychiatric phenotypes like schizophrenia, mood disorders, alcohol dependence [161], and personality traits [162]. However, the association of this polymorphism with obesity is still elusive as there is scarce data on it. TH mRNA expression was significantly decreased in the substantia nigra, ventromedial hypothalamic nucleus, and ventral tegmental area of the high-fat-diet-induced obese and obese-resistant mice compared to controls [163]. Individuals with central obesity had lower $T H$ expression in their peripheral blood mononuclear cells (PBMCs) compared with controls, and TH expression was also significantly negatively correlated with WC [164]. In our unpublished study, we found that Malaysian subjects with TH VNTR was not associated with obesity, but nevertheless, subjects with the T9 allele had significantly highest SBP and visceral fat level (VFL) and lowest pulse rate.

\section{VNTR in insulin gene (INS)}

Free fatty acid accumulation in the liver, adipose tissue, and skeletal muscle of obese patients interferes with normal insulin signaling, which will lead to insulin resistance [165]. As a consequence, increased insulin production (hyperinsulinemia) in the pancreas is needed to maintain normal values of glycemia, which, in turn, converts the liver into a fat-producing factory with all of its negative downstream effects [165].

A gene that may be involved in the development of metabolic syndrome is the gene codifying for insulin itself (INS). INS is located between TH and the insulinlike growth factor II gene (IGF2) on 11p15.5 [166]. Within this gene, a VNTR, positioned at $363 \mathrm{bp}$ from the INS transcription starting site (promoter region), has been largely studied in cohorts of children and adolescents $[167,168]$. Three alleles of INS VNTR have been observed in Caucasians: the common short class I (26-63 repeats) and long class III (141-209 repeats) and the rare class II (about 80 repeats) [168, 169]. Differences in steady-state levels of INS mRNA have been detected in the pancreas of a cadaver adult and fetus carrying class I and class III alleles, albeit with lower levels in the latter allele $[170,171]$.

The INS VNTR has been intensively studied for association with glucose metabolism in a number of metabolic disorders. Initially, class I allele was reported to be associated with higher risk of type 1 diabetes in UK families [168], and this finding has been consistently and reliably replicated [172]. On the other hand, class III allele was suggested to associate with higher birth weight [173], higher adult fasting glucose [174] and infant insulin [175] levels, and increased risk of T2D [176]. However, several studies failed to replicate association of class III allele with fetal growth and birth weight $[177,178]$ or reported associations with lower birth weight [174, 179]. Findings on the INS VNTR association with T2D were 
also mainly not successfully replicated [180, 181], although a modest association was reported in a familybased study [182].

The putative contribution of the INS VNTR in the genetic risk for obesity was first investigated in children. Strong evidence for a family-based association with 1.8fold increased risk of early-onset obesity for class I allele was found, when this allele is paternally inherited [183]. An earlier study by the same group has suggested higher insulin levels in obese children carrying the class I allele [171]. However, several studies of the association of INS VNTR with body composition and insulin levels in cohorts of children were inconclusive [184-187]; for example, large Finnish birth cohort [180] and UK population of middle-aged adults [188] studies failed to find any significant association. The relevance of studies employing unrelated individuals has been criticized [189], due to heredity complexity and transmission distortion of the INS VNTR [190]. However, in a family-based design in more than 1000 French or German Caucasian families, this VNTR was not associated with childhood obesity and variance of insulin resistance, insulin secretion, and birth weight [191].

\section{VNTRs in inflammatory cytokine genes}

\section{Interleukin-1 receptor antagonist gene (IL1RA)}

Interleukin-1 receptor antagonist (IL-1ra), also known as IL-1RN, is an endogenous competitive inhibitor of proinflammatory IL- $1 \alpha$ and IL-1 $\beta$ [192]. IL-1ra is a proadipogenic factor as it is highly secreted by the white adipose tissue [193], and IL1RA knockout mice have impaired adipogenesis and reduced adipose storage [194]. The IL-1ra level is increased in the serum of obese patients, correlating with BMI and insulin resistance [195]. A 86-bp VNTR is found within intron 2 of IL1RA, and to date, six distinct alleles corresponding to $1,2,3,4,5$, and 6 copies of the VNTR have been identified [196]. The 4-repeat (allele I) and 2-repeat (allele II) are most frequently found in the general population, while the other four (alleles III, IV, V, and VI) are rarely observed [197]. This VNTR, particularly homozygosity for allele II, has been variably associated with various conditions such as obesity, inflammatory bowel disease, and coronary artery disease (reviewed in [198]). IL1RA allele II has a clear influence on IL-1ra circulating levels since in normal human subjects, its carrier had higher levels than the noncarrier individuals [199]. With regard to obesity, two previous Asian studies with relatively small sample sizes found no significant association between IL1RA VNTR and BMI in Koreans [200] and North Indians [201]. Similarly, our study found no association with BMI value or overall obesity status, but IL1RA II allele VNTR was associated with higher TBF value and higher risk for overall adiposity [202].

\section{Interleukin-4 gene (IL4)}

IL-4, secreted by activated Th2 lymphocytes, basophils, and mast cells, executes many biological roles such as induction of Th2 differentiation, B cell proliferation, and immunoglobulin class switching [203]. In animal studies, mice treated with IL-4 had improved insulin sensitivity and glucose tolerance while lipid accumulation in adipose tissues was inhibited [204, 205], while rats receiving visceral fat removal surgery had decreased serum IL-4 [206]. The role of IL-4 in modulating adipogenesis has been established by previous studies [207, 208]. Similar to IL1RA, IL4 has a 70-bp VNTR polymorphism within intron 3, and two common alleles are B1 and B2 that have two and three tandem repeats, respectively [209]. This VNTR could be a functional polymorphism as it could affect mRNA splicing, leading to different splice variants [210]. Indeed, the B2 allele has been associated with a reduced amount of peripheral Th cells which produce IL-4 [211]. There have been several reports on the association between the VNTR B1 allele and inflammatory diseases, such as multiple sclerosis [212], rheumatoid arthritis [213], and systemic lupus erythematosus [214]. With regard to obesity, there are limited studies on this VNTR, where two studies showed no association $[215,216]$. Our study showed that this VNTR was associated with overall adiposity status (TBF class), but not with TBF value after adjustment for ethnicity [202]. A previous study in north Indians also showed that the B2B2 genotype was associated with higher risk for T2D [217].

\section{Other INDELs and VNTRs}

\section{Endothelial nitric oxide synthase gene (eNOS/NOS3)}

Nitric oxide (NO) is synthesized from L-arginine by nitric oxide synthase (NOS). There are at least three isoenzymes of NOS: constitutive neuronal NOS (nNOS or NOS-1), inducible NOS (iNOS or NOS-2), and constitutive endothelial NOS (eNOS or NOS-3), located on different chromosomes and expressed in different cell lines [218]. eNOS has been described as a major regulator of adipose tissue metabolism and energy balance by affecting lipolysis [219]. The adipose tissue and skeletal muscle of obese humans and rodents have decreased eNOS [220-222].

eNOS has been reported to possess approximately 303 variations including a VNTR at intron 4, intron 13 with a CA repeat, and enormous SNPs. There are three variations which are putatively functional and studied frequently, namely Glu298Asp, 27-bp VNTR intron 4a/ $\mathrm{b}$, and T-786C [223]. At the 27-bp VNTR, a larger (b) allele comes with five tandem repeats while a smaller (a) allele comes with four tandem repeats [223]. Plasma NO levels were found to be significantly lower in individuals homozygous for the (b) allele than in those homozygous 
for the (a) allele, suggesting a role of this VNTR in the regulation of eNOS expression [224, 225]. Indeed, this VNTR might have a cis-acting role in eNOS promoter function [226]. Others revealed that this VNTR produces small microRNAs that induce significant eNOS-specific transcriptional suppression by altering histone acetylation and DNA methylation [227]. Specifically, the (b) allele could result in increased microRNA expression and reduced eNOS mRNA levels [228]. Overall, these studies highlight that the (b) allele correlates with reduced eNOS expression and reduced NO levels, which may lead to low fat oxidation over time and a mild progression of increase in body fat [229].

A pioneer study investigating the effect of this VNTR on obesity in a sample of the Tunisian population found that carriers of the (b) allele presented 1.7 times higher risk of obesity [230]. Correlations with anthropometric parameters also revealed that carriers of the bb genotype had significantly higher BMI compared to those homozygous for the (a) allele [231]. Although this VNTR has not been reported to be associated with T2D, other eNOS SNPs are associated with T2D [231] and insulin resistance [232-234]. eNOS SNPs also appear to increase susceptibility for hypertriglyceridemia and low HDL [235] and worsen endothelial function in individuals prone to T2D [236]. However, neither the eNOS VNTR allele, genotype, nor their combination with angiotensinconverting enzyme $(A C E)$ INDEL, apolipoprotein $\mathrm{E}$ (APOE $\varepsilon 2, \varepsilon 3, \varepsilon 4$ ), and LEP G2548A presented as a risk for hypertension, elevated triglycerides, and total, LDL, or HDL cholesterol in the Roma minority population of Croatia [237].

\section{Angiotensin-converting enzyme gene (ACE)}

ACE, a key enzyme in the renin-angiotensin system (RAS), converts angiotensin I into vasoconstrictor molecule angiotensin II [238]. Body fat and body weight could be raised and lowered accordingly by stimulating and inhibiting the production of Ang II [239], suggesting a possible link between ACE and obesity (reviewed in [240]). In 1990, Rigat et al. first described an INDEL in $A C E$, defined as either the presence (insertion, I) or absence (deletion, D) of a 287-bp insert in intron 16 of the gene on chromosome 17q23 (dbSNP rs1799752) [241]. This INDEL has been proposed as a genetic marker for a variety of disease conditions (reviewed in [242]), ranging from mainly cardiovascular diseases like essential hypertension [243], myocardial infarction [244], and hypertrophic cardiomyopathy [245] to obesity-related complications such as metabolic syndrome [246], T2D [247], and reduced HDL-C levels [248].

Research on the association of this INDEL with obesity specifically has been growing in the past two decades, mainly showing the role of the D allele or DD genotype in increased risk for overweight/obesity. The DD genotype was associated with larger increases in body weight and BP in older Italian men, as well as with higher incidence of overweight [249]. Spanish subjects with coronary heart disease (CHD) and DD/ID genotypes had significantly higher prevalence of obesity and abdominal fat deposit and higher values of weight and WC [250]. The DD genotype and D allele occurred at a higher frequency in obese Saudi [251] and Turkish [252] individuals. The $\mathrm{D}$ allele was associated with increased BMI, WC, and body fat mass in Brazilian boys, independent of the association with BP [253]. The DD genotype also heightened the effects of traditional risk factors for obesity, for example by increasing the magnitude of the association between childhood gain in upper body adiposity, insulin resistance, and hypertriglyceridemia [254] and by increasing carbohydrate intake in morbidly obese Czech population [255]. In contrast, our study found that Malaysian subjects with the II genotype and I allele were, respectively, 2.15 and 1.55 times more likely to be centrally obese, but when adjusted for age and ethnicity, this association was abolished [256]. However, other studies reported that this INDEL was not associated with obesity-related traits in overweight sedentary American women [257], Korean women [258, 259], and a large sample of Chinese patients with T2D [260].

\section{Dedicator of cytokinesis 5 gene (DOCK5)}

In-depth investigation of a complex region on chromosome 8p21.2 encompassing DOCK5 which includes two VNTRs of complex sequence composition (one in $5^{\prime}$ UTR and another in intron 1 of DOCK5) which flank a common 3975-bp INDEL (in intron 1 of DOCK5) found a significant association of these VNTRs and INDEL with childhood and adult severe obesity [261]. Support for a functional effect of the DOCK5 VNTRs and deletion was also evidenced by the association between DOCK5 transcript levels and variants in adipose tissue from a Swedish family sample [261]. The mechanism of how DOCK5 could contribute to obesity is currently unknown, but it has been postulated that DOCK5, a member of the DOCK family of guanine nucleotide exchange factors, could bind to protein phosphatase 2 to inactivate $\mathrm{v}$-akt murine thymoma viral oncogene homolog (Akt) proteins and mitogen-activated protein kinases 1 and 3 (MAPK1 and 3), modulating the anorectic effects of leptin [261].

\section{Period circadian clock 3 gene (PER3)}

A 54-bp VNTR in exon 18 of PER3 defined as four repeats (4 allele) or five repeats (5 allele) in humans [262] has been associated with sleep behavior [263]. Particularly, the PER3 5/5 genotype was associated with increased morning preference, earlier wake and bed time, 
Table 1 Summary of INDELs and VNTRs that have been studied for association with common polygenic obesity and its related traits and complications

\begin{tabular}{|c|c|c|c|}
\hline Gene/nearest gene & INDEL/NNTR & Type(s) [pivotal reference] & Location in human chromosome \\
\hline$\overline{\text { FTO }}$ & INDELS & $\begin{array}{l}13 \text { insertions and } 27 \text { deletions ( } 1-9 \mathrm{bp})-16 \text { known in } \\
\mathrm{dbSNP} \text { and } 24 \text { potentially novel [37] }\end{array}$ & hg18, chr16: 52307514-52699069 \\
\hline LEP & VNTR & $\begin{array}{l}\text { (CTTT)n } \\
\text { Type } 1 \text { allele: } 121-145 \text { [49] or 146-178 bp [51] } \\
\text { Type } 2 \text { allele: } 197-225 \text { [49] or 165-193 bp [51] } \\
\text { Type } 3 \text { allele: } 210-254 \text { bp [51] }\end{array}$ & $\begin{array}{l}3912 \mathrm{bp} 3^{\prime} \text { of the LEP stop codon } \\
\text { ( } 476 \mathrm{bp} 3^{\prime} \text { of the } 3^{\prime} \text { UTR) }\end{array}$ \\
\hline \multirow[t]{7}{*}{$\angle E P R$} & \multirow[t]{5}{*}{ STR/NNTR } & $\begin{array}{l}\text { D1S200: (CA)n; } 13-27 \text { repeats; } 17 \text { most } \\
\text { common }[56,57]\end{array}$ & UniSTS: 56325; Chr1 c.77.73 cM \\
\hline & & D1S3728 [58] & UniSTS: 56029; Chr1 c.89.49 cM \\
\hline & & D1S1665 [58] & UniSTS: 60783; Chr1 c.99.62 cM \\
\hline & & $(C A) n[59]$ & Intron 3 of LEPR \\
\hline & & $(\mathrm{CTTT}) n[59]$ & Intron 16 of LEPR \\
\hline & \multirow[t]{2}{*}{ INDEL } & CTTA [60] & 3' UTR of LEPR \\
\hline & & TAT [61] & 1078Y codon of $L E P R$ \\
\hline \multirow[t]{9}{*}{ POMC } & \multirow[t]{8}{*}{ STR/NNTR } & $\begin{array}{l}\text { D2S1788: (GATA)n; } 4-20 \text { repeats; } 15 \text { most } \\
\text { common }[62,63]\end{array}$ & UniSTS: 6210; Chr2 55.51 cM \\
\hline & & D2S2170 [55] & UniSTS: 60770; Chr2 47.98 cM \\
\hline & & D2S144 [55] & UniSTS: 68025; Chr2 45.3 cM \\
\hline & & D2S1268 [55] & UniSTS: 149288; Chr2 \\
\hline & & D2S1348 [55] & UniSTS: 54913; Chr2 \\
\hline & & D2S2221 [68] & UniSTS: 32562; Chr2 46.54 cM \\
\hline & & D2S171 [68] & UniSTS: 73301; Chr2 149.4 cr3000 \\
\hline & & D2S2337 [68] & UniSTS: 14003; Chr2 47.76 cM \\
\hline & INDEL & Trinucleotide repeat (9 bp) [69] & Exon 3 of POMC (codon 94) \\
\hline \multirow[t]{8}{*}{ MC4R } & \multirow[t]{8}{*}{ STRNNTR } & D18S851 [81] & UniSTS: 39301; Chr18 382.9 cr3000 \\
\hline & & D18S487 [81] & UniSTS: 84391; Chr18 20924 cr50000 \\
\hline & & D18569 [81] & UniSTS: 47737; Chr18 2049 cr10000 \\
\hline & & $\begin{array}{l}\text { D18S858 [81]; 8-20 repeats; 11/12 most } \\
\text { common [57] }\end{array}$ & UniSTS: 14041; Chr18 80.41 cM \\
\hline & & D18S849 [81] & UniSTS: 15592; Chr18 430.2 cr3000 \\
\hline & & D18S1155 [81] & UniSTS: 32047; Chr18 81.27 cM \\
\hline & & D18S64 [81] & UniSTS: 17561; Chr18 84.8 cM \\
\hline & & D18S38 [81] & UniSTS: 14742; Chr18 84.98 cM \\
\hline \multirow[t]{2}{*}{ UCP2 } & STRNNTR & D11S912 $[4,57,81]$ & UniSTS: 72663; Chr11 137.93 cM \\
\hline & INDEL & 45 bp [88] & 3' UTR of UCP2 exon 8 \\
\hline \multirow[t]{2}{*}{ SLC6A4/5HTT } & \multirow[t]{2}{*}{ VNTR } & $\begin{array}{l}\text { 5-HTTLPR } 43 \text { bp; 14R (short, S) and 16R (long, L) } \\
\text { alleles [102] }\end{array}$ & $\begin{array}{l}1 \mathrm{~kb} \text { upstream of the SLC6A4/5HTT } \\
\text { transcription start site }\end{array}$ \\
\hline & & $\begin{array}{l}\text { STin2 } 17 \text { bp; common 10- and 12-repeat alleles } \\
\text { and a rare 9-repeat allele }[103,104]\end{array}$ & Intron 2 of SLC6A4/5HTT \\
\hline SLC6A3/DAT1 & VNTR & 40 bp; 9-repeat (S) and 10-repeat (L) alleles [118] & 3' UTR of SLC6A3/DAT1 \\
\hline DRD2 & INDEL & 1 bp; dbSNP rs1799732; -141C [121] & 5' UTR of DRD2 \\
\hline DRD4 & VNTR & $\begin{array}{l}48 \text { bp; } 2-10 \text { repeats; } 4 \text {-repeat ( } 4 \mathrm{R} \text { or } \mathrm{S}) \text { and } \\
\text { 7-repeat (7R or } \mathrm{L} \text { ) alleles most common [132] }\end{array}$ & Exon 3 of DRD 4 \\
\hline$M A O A$ & VNTR & $\begin{array}{l}30 \text { bp; 2-, 3-, 3.5-, 4-, 5-, or 6-repeat copies [151]; } \\
\text { 3- and 4-repeat alleles most common [146] }\end{array}$ & Promoter region of $M A O A$ \\
\hline TH & VNTR & $(\mathrm{TCAT})_{n i} ; \mathrm{T} 6, \mathrm{~T} 7, \mathrm{~T} 8, \mathrm{~T} 9$, and T10 alleles [157] & Intron 1 of $T H$ \\
\hline
\end{tabular}


Table 1 Summary of INDELS and VNTRs that have been studied for association with common polygenic obesity and its related traits and complications (Continued)

\begin{tabular}{|c|c|c|c|}
\hline INS & VNTR & $\begin{array}{l}\text { 14-15 bp; short class I allele ( } \sim 570 \text { bp, } 26-63 \text { repeats), } \\
\text { class II alleles ( } \sim 1320 \text { bp, about } 80 \text { repeats), and } \\
\text { the long class III ( } \sim 2470,141-209 \text { repeats) [167] }\end{array}$ & $\begin{array}{l}63 \text { bp from the INS transcription } \\
\text { starting site (promoter region) }\end{array}$ \\
\hline ILIRA & VNTR & $\begin{array}{l}86 \text { bp; 1, 2, 3, 4, 5, and } 6 \text { repeats; 4-repeat (allele I) } \\
\text { and 2-repeat (allele II) most common [196] }\end{array}$ & Intron 2 of ILIRA \\
\hline IL4 & VNTR & $\begin{array}{l}70 \text { bp; 2-repeat (B1) and 3-repeat (B2) alleles } \\
\text { most common [209] }\end{array}$ & Intron 3 of IL4 \\
\hline eNOS/NOS3 & VNTR & $\begin{array}{l}27 \text { bp; 4-repeat (a) and 5-repeat (b) alleles most } \\
\text { common [223] }\end{array}$ & Intron 4 of eNOS/NOS3 \\
\hline$A C E$ & INDEL & 287 bp; dbSNP rs1799752 [241] & Intron 16 of $A C E$ \\
\hline \multirow[t]{3}{*}{ DOCK5 } & VNTR & VNTR A; 590-640-bp allele [261] & $\begin{array}{l}\text { chr8: } 25085372-25085875 ; ~ 12 \mathrm{~kb} \\
\text { upstream of DOCK5 }\end{array}$ \\
\hline & & $\begin{array}{l}\text { VNTR B; 944-1022-, 1112-1127-, 1073-1084-, } \\
\text { and 1099-1103-bp alleles [261] }\end{array}$ & $\begin{array}{l}\text { chr8: } 25129579-25130501 \text {; intron } 1 \\
\text { of DOCK5 }\end{array}$ \\
\hline & INDEL & 3975 bp [261] & $\begin{array}{l}\text { chr8: } 25122602-25126576 \text {; intron } 1 \\
\text { of DOCK5 }\end{array}$ \\
\hline PER3 & VNTR & 54 bp; 4-repeat and 5-repeat alleles [262] & Exon 18 of PER3 \\
\hline
\end{tabular}

and reduced daytime sleepiness [264]. In a single study, this VNTR has been investigated for association with obesity-related anthropometric traits, sleep, and nutritional behavior [265]. No association with obesity was found. Nevertheless, individuals with the 55 genotype had a higher percentage of daily energy derived from fat, had a lower percentage of daily energy derived from carbohydrates, and were more prone to an age-dependent increase in cholesterol intake [265].

\section{Points of concern}

A review paper on the role of INDELs and VNTRs in obesity is virtually nonexistent. Hence, this paper reviews the types of INDELs and VNTRs that have been studied for association with obesity and its related traits and complications, as summarized in Table 1. Some studies showed significant associations between INDELs/ VNTRs and obesity-related traits whereas other studies were not the case.

Before the establishment of SNP-based GWAS genotyping platforms like SNP microarray, INDELs and VNTRs were commonly used as a genetic maker for linkage and candidate gene association analyses of polygenic traits including obesity, as evidenced by the numerous obesity sequence tagged sites (STSs) as stated in the earlier part of the review. This is because genotyping of INDELs and VNTRs is easy with low-resolution gel electrophoresis methods. Virtually, obesity loci identified in the past studies using INDELs or VNTRs were not replicated in the SNP-based GWAS with enough sample sizes. It suggests that the many of old-fashioned obesity loci were unfortunately false positive. Besides insufficient sample size, these false positive loci could also be attributed to the other reasons as outlined by Li and Meyre
[10], which include nonheritable phenotype, improper correction for multiple testing, population stratification, technical biases, insufficient quality control, or inappropriate statistical analyses.

Even if an original study describes a true positive association for a particular INDEL/VNTR, replication could be challenging, as evidenced by the discrepancies of findings in the association studies described in this review. Again, the reasons as outlined by $\mathrm{Li}$ and Meyre [10] include underpowered replication samples, interaction between genes themselves and with the environment, genetic heterogeneity (due to ethnicity), phenotypic heterogeneity (different definitions, measurements, and categorizations for obesity), and subjective interpretation of data.

Some of these pitfalls in obesity loci discovery and replication genetic association studies could be overcome by following the recommendations by Li and Meyre [10] and the STrengthening the Reporting of OBservational studies in Epidemiology - Molecular Epidemiology (STROBE-ME) statement [266].

\section{Conclusions}

INDELs and VNTRs have significant functional consequences by regulating gene transcription, translation efficiency, and stability of mRNA or by modifying the activity of proteins by altering their structure. The final publication of the phase 31000 Genomes Project in October 2015, which has 3.4 million bi-allelic INDELs and 60,000 structural variants [267], has provided a marker set for the imputation of genotypes in recent GWAS. Common INDELs and VNTRs that are in the promoters and exons or have been studied before in previous candidate gene association studies could be highly 
prioritized in the candidate gene approach in finding obesity loci. INDELs and VNTRs would greatly expand the number of high-scoring variants besides SNPs that are identified in obesity candidate gene studies and GWAS. As an association does not always imply causality, biological insights are essential in increasing the credibility of the observed genetic association. Therefore, in silico, in vitro, and ex vivo functional characterization assays of the INDELs and VNTRs could then be performed, especially for novel genes, to elucidate the mechanistic effects of the risk alleles in plausible biological pathways involved in obesity. This could be followed by comprehensive in vivo animal studies to ultimately identify the risk allele as a causal variant for obesity and/or its related traits and complications. Inclusion of INDELs and VNTRs in genetic association studies would help in defining the genetic architecture of complex traits and diseases like obesity and also to provide new insights into its normal physiology and disease pathophysiology. Identification of the causal relationships between INDELs and VNTRs and obesity risk would facilitate the prediction of obesity onset, early diagnosis of obesity, and the development of novel and potentially patient-specific therapeutic targets.

\section{Abbreviations}

5-HT: Serotonin; AN: Anorexia nervosa; BMl: Body mass index; bp: Base pair; BP: Blood pressure; CNV: Copy number variation; DA: Dopamine; DOCK5: Dedicator of cytokinesis 5 gene; DRD2: Dopamine receptor D2 gene; DRD4: Dopamine receptor D4 gene; eNOS/NOS3: Endothelial nitric oxide synthase gene; FTO: Fat mass and obesity-associated protein gene; GIANT: Genetic Investigation of Anthropometric Traits; GWAS: Genome-wide association study; HDL-C: High-density lipoprotein cholesterol; ILIRA: Interleukin-1 receptor antagonist gene; IL4: Interleukin-4 gene; INDEL: Insertion/deletion; INS: Insulin gene; LEP: Leptin gene; LEPR: Leptin receptor gene; LDL: Low-density lipoprotein; LOF: Loss-of-function; MAOA: Monoamine oxidase A gene; MC4R: Melanocortin 4 receptor gene; NO: Nitric oxide; NOS: Nitric oxide synthase; PER3: Period circadian clock 3 gene; POMC: Proopiomelanocortin gene; RAS: Renin-angiotensin system; SBP: Systolic blood pressure; SF: Subcutaneous fat; SLC6A3/DAT1: Dopamine transporter gene; SLC6A4/5HTT: 5-Hydroxytryptamine (serotonin) transporter gene; SNP: Single nucleotide polymorphisms; STR: Short tandem repeat; STS: Sequence tagged site; T2D: Type 2 diabetes; TBF: Total body fat; $T H$ : Tyrosine hydroxylase gene; UCP2: Uncoupling protein 2 gene; UCP3: Uncoupling protein 3 gene; VFL: Visceral fat level; VNTR: Variable number tandem repeat; WC: Waist circumference; WHR: Waist-hip ratio
\end{abstract}

\section{Acknowledgements}

The author would like to thank his past and present undergraduate and postgraduate students for their work cited in this review.

\section{Funding}

Our work has been funded by the UTAR Research Funds-IPSR/RMC/ UTARRF/2013-C2/S01, IPSR/RMC/UTARRF/C111/C35, IPSR/RMC/UTARRF/C109/ S1 - and by the Department of Biomedical Science, UTAR.

\section{Availability of data and materials}

Not applicable.

\section{Authors' contributions}

YHS wrote, read, and approved the final version of the manuscript.

\section{Competing interests}

The author declares that he has no competing interests.
Consent for publication

Not applicable.

Ethics approval and consent to participate

Our experiments received institutional ethical approval from the UTAR Scientific and Ethical Review Committee (SERC), and written informed consent was obtained from each participant.

\section{Publisher's Note}

Springer Nature remains neutral with regard to jurisdictional claims in published maps and institutional affiliations.

Received: 10 April 2017 Accepted: 1 June 2017

Published online: 14 June 2017

\section{References}

1. $\mathrm{Ng} \mathrm{M}$, et al. Global, regional, and national prevalence of overweight and obesity in children and adults during 1980-2013: a systematic analysis for the Global Burden of Disease Study 2013. Lancet. 2014;384:766-81.

2. Obesity and overweight. http://www.who.int/mediacentre/factsheets/fs311/ en/. Accessed 28 Mar 2017.

3. Maes HH, Neale MC, Eaves LJ. Genetic and environmental factors in relative body weight and human adiposity. Behav Genet. 1997:27:325-51.

4. Atwood LD, et al. Genome-wide linkage analysis of body mass index across 28 years of the Framingham Heart Study. Am J Hum Genet. 2002:71:1044-50.

5. Kamel EG, McNeill G, Van Wijk MC. Usefulness of anthropometry and DXA in predicting intra-abdominal fat in obese men and women. Obes Res. 2000:8:36-42.

6. Montague $\mathrm{CT}$, et al. Congenital leptin deficiency is associated with severe early-onset obesity in humans. Nature. 1997:387:903-8.

7. Clement $\mathrm{K}$, et al. A mutation in the human leptin receptor gene causes obesity and pituitary dysfunction. Nature. 1998;392:398-401.

8. Krude $\mathrm{H}$, et al. Obesity due to proopiomelanocortin deficiency: three new cases and treatment trials with thyroid hormone and ACTH4-10. J Clin Endocrinol Metab. 2003;88:4633-40.

9. Vaisse C, Clement K, Durand E, Hercberg S, Guy-Grand B, Froguel P. Melanocortin-4 receptor mutations are a frequent and heterogeneous cause of morbid obesity. J Clin Invest. 2000;106:253-62.

10. Li A, Meyre D. Challenges in reproducibility of genetic association studies: lessons learned from the obesity field. Int J Obes. 2013;37:559-67.

11. McPherson JD, et al. A physical map of the human genome. Nature. 2001; 409:934-41.

12. The International HapMap Consortium. A haplotype map of the human genome. Nature. 2005;437:1299-320.

13. Herbert A, et al. A common genetic variant is associated with adult and childhood obesity. Science. 2006;312:279-83.

14. Naidoo N, Pawitan Y, Soong R, Cooper DN, Ku CS. Human genetics and genomics a decade after the release of the draft sequence of the human genome. Hum Genomics. 2011:5:577-622.

15. Willer CJ, et al. Six new loci associated with body mass index highlight a neuronal influence on body weight regulation. Nat Genet. 2009:41:25-34.

16. Fall $\mathrm{T}$, Ingelsson E. Genome-wide association studies of obesity and metabolic syndrome. Mol Cell Endocrinol. 2014;382:740-57.

17. Mills RE. Natural genetic variation caused by small insertions and deletions in the human genome. Genome Res. 2011;21:830-9.

18. Nakamura Y, Koyama K, Matsushima M. VNTR (variable number of tandem repeat) sequences as transcriptional, translational, or functional regulators. J Hum Genet. 1998:43:149-52.

19. Brookes KJ. The VNTR in complex disorders: the forgotten polymorphisms? A functional way forward? Genomics. 2013;101:273-81.

20. Tautz D. Hypervariability of simple sequences as a general source for polymorphic DNA markers. Nucleic Acids Res. 1989;17:6463-471.

21. Jeffreys AJ, Wilson $V$, Thein SL. Hypervariable 'minisatellite' regions in human DNA. Nature. 1985:314:67-73.

22. Jeffreys AJ, et al. Human minisatellites, repeat DNA instability and meiotic recombination. Electrophoresis. 1999;20:1665-75

23. International HapMap 3 Consortium, et al. Integrating common and rare genetic variation in diverse human populations. Nature. 2010;467:52-8.

24. Mullaney JM, Mills RE, Pittard WS, Devine SE. Small insertions and deletions (INDELs) in human genomes. Hum Mol Genet. 2010;19:R131-6. 
25. Fang $\mathrm{H}$, et al. Reducing INDEL calling errors in whole genome and exome sequencing data. Genome Med. 2014;6:89.

26. Karakoc $E$, et al. Detection of structural variants and indels within exome data. Nat Methods. 2011;9:176-8.

27. Fondon III JW, et al. Simple sequence repeats: genetic modulators of brain function and behavior. Trends Neurosci. 2008:31:328-34.

28. Ratan A, Olson TL, Loughran Jr TP, Miller W. Identification of indels in nextgeneration sequencing data. BMC Bioinform. 2015;16:42.

29. Gelfand Y, Hernandez Y, Loving J, Benson G. VNTRseek—a computational tool to detect tandem repeat variants in high-throughput sequencing data. Nucleic Acids Res. 2014;42:8884-94.

30. Frayling TM, et al. A common variant in the FTO gene is associated with body mass index and predisposes to childhood and adult obesity. Science. 2007;316:889-94

31. Dina C, Meyre D, Gallina S, et al. Variation in FTO contributes to childhood obesity and severe adult obesity. Nat Genet. 2007;39:724-26.

32. Yang J, et al. FTO genotype is associated with phenotypic variability of body mass index. Nature. 2012;490:267-72.

33. Loos RJ, Yeo GS. The bigger picture of FTO: the first GWAS-identified obesity gene. Nat Rev Endocrinol. 2014;10:51-61.

34. Claussnitzer M, et al. FTO obesity variant circuitry and adipocyte browning in humans. N Engl J Med. 2015;373:895-907.

35. Tonjes $\mathrm{A}$, et al. Association of FTO variants with BMl and fat mass in the selfcontained population of Sorbs in Germany. Eur J Hum Genet. 2010;18:104-10.

36. Adeyemo A, et al. FTO genetic variation and association with obesity in West Africans and African Americans. Diabetes. 2010;59:1549-54.

37. Sällman Almén $M$, et al. Determination of the obesity-associated gene variants within the entire FTO gene by ultra-deep targeted sequencing in obese and lean children. Int J Obes (Lond). 2013;37:424-31.

38. Zhang Y, Proenca R, Maffei M, Barone M, Leopold L, Friedman JM. Positional cloning of the mouse obese gene and its human homologue. Nature. 1994; 372:425-32.

39. Strobel A, Issad T, Camoin L, Ozata M, Strosberg AD. A leptin missense mutation associated with hypogonadism and morbid obesity. Nat Genet. 1998;18:213-5.

40. Ahima RS, Flier JS. Leptin. Annu Rev Physiol. 2000;62:413-37.

41. Baile CA, Della-Fera MA, Martin RJ. Regulation of metabolism and body fat mass by leptin. Ann Rev Nutr. 2000:20:105-27.

42. Speliotes EK, et al. Association analyses of 249,796 individuals reveal 18 new loci associated with body mass index. Nat Genet. 2010:42:937-48.

43. Borecki IB, Rice T, Perusse L, Bouchard C, Rao DC. An exploratory investigation of genetic linkage with body composition and fatness phenotypes: the Quebec Family Study. Obes Res. 1994;2:213-9.

44. Clement $\mathrm{K}$, et al. Indication for linkage of the human $\mathrm{OB}$ gene region with extreme obesity. Diabetes. 1996;45:687-90.

45. Duggirala $R$, et al. Quantitative variation in obesity-related traits and insulin precursors linked to the $\mathrm{OB}$ gene region on human chromosome 7. Am J Hum Genet. 1996;59:694-703.

46. Reed DR, Ding Y, Xu W, Cather C, Green ED, Price RA. Extreme obesity may be linked to markers flanking the human OB gene. Diabetes. 1996;45:691-4.

47. Oksanen $L$, et al. Markers for the gene ob and serum leptin levels in human morbid obesity. Hum Genet. 1997;99:559-64.

48. Allison DB, Heo M. Meta-analysis of linkage data under worst-case conditions: a demonstration using the human OB region. Genetics. 1998;148:859-65.

49. Shintani $\mathrm{M}$, et al. A novel microsatellite polymorphism in the human $\mathrm{OB}$ gene: a highly polymorphic marker for linkage analysis. Diabetologia. 1996; 39:1398-401.

50. Shintani $\mathrm{M}$, et al. Leptin gene polymorphism is associated with hypertension independent of obesity. J Clin Endocrinol Metab. 2002;87:2909-12.

51. Moffett $\mathrm{S}$, et al. Genetic diversity and evolution of the human leptin locus tetranucleotide repeat. Hum Genet. 2002;110:412-7.

52. Hinuy HM, Hirata MH, Sampaio MF, Armaganijan D, Salazar LA, Hirata RD. LEP $3^{\prime} H V R$ is associated with obesity and leptin levels in Brazilian individuals. Mol Genet Metab. 2006;89:374-80.

53. Hinuy HM, et al. Relationship between variants of the leptin gene and obesity and metabolic biomarkers in Brazilian individuals. Arq Bras Endocrinol Metabol. 2010;54:282-8.

54. de Silva AM, Walder KR, Aitman TJ, Gotoda T, Goldstone AP, Hodge AM, de Courten MP, Zimmet PZ, Collier GR. Combination of polymorphisms in OB-R and the $\mathrm{OB}$ gene associated with insulin resistance in Nauruan males. Int Obes Relat Metab Disord. 1999;23(8):816-22.
55. McGarvey ST, et al. Human leptin locus (LEP) alleles and BMI in Samoans. Int J Obes Relat Metab Disord. 2002;26:783-8.

56. Chagnon YC, et al. Suggestive linkages between markers on human 1p32p22 and body fat and insulin levels in the Quebec Family Study. Obes Res. 1997;5:115-21.

57. Hinuy HM, et al. Relationship of short tandem repeats flanking leptinmelanocortin pathway genes with anthropometric profile and leptinemia in Brazilian individuals. Arq Bras Endocrinol Metabol. 2012;56:47-53.

58. van der Kallen CJ, et al. Genome scan for adiposity in Dutch dyslipidemic families reveals novel quantitative trait loci for leptin, body mass index and soluble tumor necrosis factor receptor superfamily 1A. Int I Obes Relat Metab Disord. 2000;24:1381-91.

59. Chagnon YC, Chung WK, Pérusse L, Chagnon M, Leibel RL, Bouchard C. Linkages and associations between the leptin receptor (LEPR) gene and human body composition in the Québec Family Study. Int J Obes Relat Metab Disord. 1999;23:278-86.

60. Salopuro T, et al. Genetic variation in leptin receptor gene is associated with type 2 diabetes and body weight: the Finnish Diabetes Prevention Study. Int J Obes (Lond). 2005;29:1245-51.

61. Mariman EC, Bouwman FG, Aller EE, van Baak MA, Wang P. Extreme obesity is associated with variation in genes related to the circadian rhythm of food intake and hypothalamic signaling. Physiol Genomics. 2015;47:225-31.

62. Comuzzie AG, et al. A major quantitative trait locus determining serum leptin levels and fat mass is located on human chromosome 2. Nat Genet. 1997:15:273-6.

63. Hixson JE, et al. Normal variation in leptin levels in associated with polymorphisms in the proopiomelanocortin gene, POMC. J Clin Endocrinol Metab. 1999:84:3187-91.

64. Hager J, et al. A genome-wide scan for human obesity genes shows evidence for a major susceptibility locus on chromosome 10. Nat Genet. 1998;20:304-8.

65. Rotimi CN, Comuzzie AG, Lowe WL, Luke A, Blangero J, Cooper RS. The quantitative trait locus on chromosome 2 for serum leptin levels is confirmed in African-Americans. Diabetes, 1999:48:643-4.

66. Cai G, Cole SA, Bastarrachea RA, Maccluer JW, Blangero J, Comuzzie AG. Quantitative trait locus determining dietary macronutrient intakes is located on human chromosome 2p22. Am J Clin Nutr. 2004;80:1410-4.

67. Moslehi R, Goldstein AM, Beerman M, Goldin L, Bergen AW, Framingham Heart Study. A genome-wide linkage scan for body mass index on Framingham Heart Study families. BMC Genet. 2003;4:S97.

68. Delplanque J, et al. Linkage and association studies between the proopiomelanocortin (POMC) gene and obesity in Caucasian families. Diabetologia. 2000;43:1554-7.

69. Morris JC, Bertram CE, Lowry PJ, Savva D. Cryptic trinucleotide repeat polymorphism in the POMC gene. Hum Mol Genet. 1994;3:2080.

70. Rosmond R, Ukkola O, Bouchard C, Björntorp P. Polymorphisms in exon 3 of the proopiomelanocortin gene in relation to serum leptin, salivary cortisol, and obesity in Swedish men. Metabolism. 2002;51:642-4.

71. Echwald SM, Sørensen TI, Andersen T, Tybjaerg-Hansen A, Clausen JO, Pedersen $\mathrm{O}$. Mutational analysis of the proopiomelanocortin gene in Caucasians with early onset obesity. Int J Obes Relat Metab Disord. 1999;23:293-8.

72. Suviolahti $\mathrm{E}$, et al. Pro-opiomelanocortin gene is associated with serum leptin levels in lean but not in obese individuals. Int J Obes Relat Metab Disord. 2003:27:1204-11.

73. Tao YX. Molecular mechanisms of the neural melanocortin receptor dysfunction in severe early onset obesity. Mol Cell Endocrinol. 2005;239:1-14.

74. Hinney A, Volckmar AL, Knoll N. Melanocortin-4 receptor in energy homeostasis and obesity pathogenesis. Prog Mol Biol Transl Sci. 2013;114: 147-91.

75. Yeo GS, Faroogi IS, Aminian S, Halsall DJ, Stanhope RG, O'Rahilly S. A frameshift mutation in MC4R associated with dominantly inherited human obesity. Nat Genet. 1998;20:111-2.

76. Vaisse C, Clement K, Guy-Grand B, Froguel P. A frameshift mutation in human MC4R is associated with a dominant form of obesity. Nat Genet. 1998:20:113-4.

77. Hinney A, et al. Several mutations in the melanocortin-4 receptor gene including a nonsense and a frameshift mutation associated with dominantly inherited obesity in humans. J Clin Endocrinol Metab. 1999;84:1483-6.

78. Loos RJ, et al. Common variants near MC4R are associated with fat mass, weight and risk of obesity. Nat Genet. 2008:40:768-75. 
79. Chambers JC, et al. Common genetic variation near MC4R is associated with waist circumference and insulin resistance. Nat Genet. 2008;40:716-8.

80. Xi B, Chandak GR, Shen Y, Wang Q, Zhou D. Association between common polymorphism near the MC4R gene and obesity risk: a systematic review and meta-analysis. PLoS One. 2012;7:e45731.

81. Ohman $\mathrm{M}$, et al. Testing of human homologues of murine obesity genes as candidate regions in Finnish obese sib pairs. Eur J Hum Genet. 1999;7:117-24.

82. Pankow JS, et al. Possible locus on chromosome $18 \mathrm{q}$ influencing postural systolic blood pressure changes. Hypertension. 2000;36:471-6.

83. Fukino K, Shen L, Patocs A, Mutter GL, Eng C. Genomic instability within tumor stroma and clinicopathological characteristics of sporadic primary invasive breast carcinoma. JAMA. 2007;297:2103-11.

84. Jia JJ, Zhang X, Ge CR, Jois M. The polymorphisms of UCP2 and UCP3 genes associated with fat metabolism, obesity and diabetes. Obes Rev. 2009;10:519-26.

85. Campbell DA, Sundaramurthy D, Gordon D, Markham AF, Pieri LF. Association between a marker in the UCP-2/UCP-3 gene cluster and genetic susceptibility to anorexia nervosa. Mol Psychiatry. 1999;4:68-70.

86. Comuzzie AG, et al. Linkage exclusion analysis of the chromosome 11 region containing UCP2 and UCP3 with obesity-related phenotypes in Mexican Americans. Int J Obes Relat Metab Disord. 2000;24:1065-8.

87. Guo JJ, Liu YJ, Li MX, Yang YJ, Recker RR, Deng HW. Linkage exclusion analysis of two candidate regions on chromosomes 7 and 11: leptin and UCP2/UCP3 are not QTLs for obesity in US Caucasians. Biochem Biophys Res Commun. 2005;332:602-8.

88. Brondani LA, Assmann TS, de Souza BM, Bouças AP, Canani LH, Crispim D. Metaanalysis reveals the association of common variants in the uncoupling protein (UCP) 1-3 genes with body mass index variability. PLoS One. 2014;9:e96411.

89. Dalgaard LT, Pedersen O. Uncoupling proteins: functional characteristics and role in the pathogenesis of obesity and type II diabetes. Diabetologica. 2001:44:946-65.

90. Esterbauer $\mathrm{H}$, et al. A common polymorphism in the promoter of UCP2 is associated with decreased risk of obesity in middle-aged humans. Nat Genet. 2001;28:178-83

91. Cassell PG, et al. An uncoupling protein 2 gene variant is associated with a raised body mass index but not type II diabetes. Diabetologia. 1999;42:688-92.

92. Evans $D$, et al. Frequency of and interaction between polymorphisms in the beta3-adrenergic receptor and in uncoupling proteins 1 and 2 and obesity in Germans. Int J Obes Relat Metab Disord. 2000;24:1239-45.

93. Marti A, Corbalan MS, Forga L, Martinez-Gonzalec MA, Martinez JA. Higher obesity risk associated with the exon- 8 insertion of the UCP2 gene in a Spanish case-control study. J Nutr. 2004;20:498-501.

94. Lee $Y H$, Kim W, Yu BC, Park BL, Kim LH, Shin HD. Association of the ins/del polymorphisms of uncoupling protein 2 (UCP2) with BMI in a Korean population. Biochem Biophys Res Commun. 2008:371:767-71.

95. Say YH, et al. Uncoupling protein 2 gene (UCP2) 45-bp I/D polymorphism is associated with adiposity among Malaysian women. J Biosci. 2014;39:867-75.

96. Yanowski JA, et al. Associations between uncoupling protein 2, body composition and resting energy expenditure in lean and obese African American, white and Asian children. Am J Clin Nutr. 2000:71:1405-12.

97. Walder $\mathrm{K}$, et al. Association between uncoupling protein polymorphisms (UCP2-UCP3) and energy metabolism/obesity in Pima Indians. Hum Mol Genet. 1998;7:1431-5.

98. Fuemmeler BF, et al. Genes implicated in serotonergic and dopaminergic functioning predict BMl categories. Obesity. 2008;16:348-55.

99. Taub DR, Page J. Molecular signatures of natural selection for polymorphic genes of the human dopaminergic and serotonergic systems: a review. Front Psychol. 2016;7:857.

100. Ramamoorthy $S$, et al. Antidepressant- and cocaine sensitive human serotonin transporter: molecular cloning, expression, and chromosomal localization. Proc Natl Acad Sci U S A. 1993:90:2542-6.

101. Iurescia S, Seripa D, Rinaldi M. Looking beyond the 5-HTTLPR polymorphism: genetic and epigenetic layers of regulation affecting the serotonin transporter gene expression. Mol Neurobiol. 2016; doi: 10.1007/s12035-016-0304-6.

102. Heils $A$, et al. Allelic variation of human serotonin transporter gene expression. J Neurochem. 1996;66:2621-4.

103. Lesch KP, et al. Organization of the human serotonin transporter gene. J Neural Transm Gen Sect. 1994;95:157-62.

104. MacKenzie A, Quinn J. A serotonin transporter gene intron 2 polymorphic region, correlated with affective disorders, has allele-dependent differentia enhancer-like properties in the mouse embryo. Proc Natl Acad Sci U S A. 1999;96:15251-5.
105. Sookoian S, et al. Short allele of serotonin transporter gene promoter is a risk factor for obesity in adolescents. Obesity (Silver Spring). 2007;5:271-6.

106. Markus CR, Capello AE. Contribution of the 5-HTTLPR gene by neuroticism on weight gain in male and female participants. Psychiatr Genet. 2012;22:279-85.

107. Capello AE, Markus CR. Differential influence of the 5-HTTLPR genotype, neuroticism and real-life acute stress exposure on appetite and energy intake. Appetite. 2014;77:83-93.

108. Lan MY, Chang YY, Chen WH, Kao YF, Lin HS, Liu JS. Serotonin transporter gene promoter polymorphism is associated with body mass index and obesity in nonelderly stroke patients. J Endocrinol Invest. 2009;32:119-22.

109. Miranda RC, Genro JP, Campagnolo PD, Mattevi VS, Vitolo MR, Almeida S. Biallelic and triallelic approaches of 5-HTTLPR polymorphism are associated with food intake and nutritional status in childhood. J Nutr Biochem. 2017; 43:47-52.

110. Iordanidou $M$, et al. The serotonin transporter promoter polymorphism (5-HTTLPR) is associated with type 2 diabetes. Clin Chim Acta. 2010;411:167-71.

111. Hameed A, Ajmal M, Nasir M, Ismail M. Genetic association analysis of serotonin transporter polymorphism (5-HTTLPR) with type 2 diabetes patients of Pakistani population. Diabetes Res Clin Pract. 2015;108:67-71.

112. Bah J, et al. Further exploration of the possible influence of polymorphisms in HTR2C and 5HTT on body weight. Metabolism. 2010;59:1156-63.

113. Borkowska A, et al. Effect of the 5-HTTLPR polymorphism on affective temperament, depression and body mass index in obesity. J Affect Disord. 2015;184:193-7.

114. Mergen $H$, et al. LEPR, ADBR3, IRS-1 and 5-HTT genes polymorphisms do not associate with obesity. Endocr J. 2007;54:89-94.

115. Uzun M, Saglar E, Kucukyildirim S, Erdem B, Unlu H, Mergen H. Association of VNTR polymorphisms in DRD4, 5-HTT and DAT1 genes with obesity. Arch Physiol Biochem. 2015;121:75-9.

116. Dias H, Muc M, Padez C, Manco L. Association of polymorphisms in 5-HTT (SLC6A4) and MAOA genes with measures of obesity in young adults of Portuguese origin. Arch Physiol Biochem. 2016;122:8-13.

117. Fuke $S$, et al. The VNTR polymorphism of the human dopamine transporter (DAT1) gene affects gene expression. Pharmacogenomics J. 2001;1:152-6.

118. Sano A, Kondoh K, Kakimoto Y, Kondo I. A 40-nucleotide repeat polymorphism in the human dopamine transporter gene. Hum Genet. 1993; 91:405-6.

119. Heinz A, et al. Genotype influences in vivo dopamine transporter availability in human striatum. Neuropsychopharmacology. 2000;22:133-9.

120. Epstein $\mathrm{LH}$, et al. Dopamine transporter genotype as a risk factor for obesity in African-American smokers. Obes Res. 2002;10:1232-40.

121. Yokum S, Marti CN, Smolen A, Stice E. Relation of the multilocus genetic composite reflecting high dopamine signaling capacity to future increases in BMI. Appetite. 2015;87:38-45.

122. Shinohara $M$, et al. Eating disorders with binge-eating behaviour are associated with the $s$ allele of the 3'-UTR VNTR polymorphism of the dopamine transporter gene. J Psychiatry Neurosci. 2004;29:134-7.

123. Epstein $\mathrm{LH}$, et al. The relationship between food reinforcement and dopamine genotypes on food intake in smokers. Am J Clin Nutr. 2004;80: $82-8$

124. Epstein $\mathrm{LH}$, et al. Food reinforcement, the dopamine D2 receptor genotype, and energy intake in obese and nonobese humans. Behav Neurosci. 2007; 121:877-86.

125. Davis C, et al. Dopamine transporter gene (DAT1) associated with appetite suppression to methylphenidate in a case-control study of binge eating disorder. Neuropsychopharmacology. 2007;32:2199-206.

126. Wang G, et al. Brain dopamine and obesity. Lancet. 2001;357:354-7.

127. Volkow ND, et al. Low dopamine striatal D2 receptors are associated with prefrontal metabolism in obese subjects: possible contributing factors. Neuroimage. 2008;42:1537-43.

128. Young RM, Lawford BR, Nutting A, Noble EP. Advances in molecular genetics and the prevention and treatment of substance misuse: implications of association studies of the A1 allele of the D2 dopamine receptor gene. Addict Behav. 2004;29:1275-94.

129. Munafo MR, Matheson IJ, Flint J. Association of the DRD2 gene Taq1A polymorphism and alcoholism: a meta-analysis of case-control studies and evidence of publication bias. Mol Psychiatry. 2007;12:454-61.

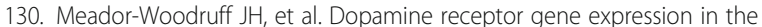
human medial temporal lobe. Neuropsychopharmacology. 1994;10:239-48.

131. Meador-Woodruff $\mathrm{JH}$, et al. Dopamine receptor mRNA expression in human striatum and neocortex. Neuropsychopharmacology. 1996;15:17-29. 
132. Van Tol HH, et al. Multiple dopamine D4 receptor variants in the human population. Nature. 1992;358:149-52.

133. Chang FM, Kidd JR, Livak KJ, Pakstis AJ, Kidd KK. The world-wide distribution of allele frequencies at the human dopamine D4 receptor locus. Hum Genet. 1996;98:91-101.

134. Schoots $\mathrm{O}$, Van Tol HH. The human dopamine D4 receptor repeat sequences modulate expression. Pharmacogenomics J. 2003;3:343-8.

135. Theisen FM, et al. Spectrum of binge eating symptomatology in patients treated with clozapine and olanzapine. J Neural Transm. 2003;110:111-21.

136. Comings DE, et al. Studies of the 48 bp repeat polymorphism of the DRD4 gene in impulsive, compulsive, addictive behaviors: Tourette syndrome, ADHD, pathological gambling, and substance abuse. Am J Med Genet. 1999;88:358-68

137. Guo G, North K, Choi S. DRD4 gene variant associated with body mass: the national longitudinal study of adolescent health. Hum Mutat. 2006;27: 236-41.

138. Levitan $\mathrm{RD}$, et al. The dopamine-4 receptor gene associated with binge eating and weight gain in women with seasonal affective disorder: an evolutionary perspective. Biol Psychiatry. 2004;56:665-9.

139. Levitan RD, et al. A birth-season/DRD4 gene interaction predicts weight gain and obesity in women with seasonal affective disorder: a seasonal thrifty phenotype hypothesis. Neuropsychopharmacology. 2006;31:2498-503.

140. Levitan RD, Kaplan AS, Davis C, Lam RW, Kennedy JL. A season-of-birth/ DRD4 interaction predicts maximal body mass index in women with bulimia nervosa. Neuropsychopharmacology. 2010;35:1729-33.

141. Eisenberg DT, Campbell B, Gray PB, Sorenson MD. Dopamine receptor genetic polymorphisms and body composition in undernourished pastoralists: an exploration of nutrition indices among nomadic and recently settled Ariaal men of northern Kenya. BMC Evol Biol. 2008;8:173.

142. Levitan RD, et al. A DRD4 gene by maternal sensitivity interaction predicts risk for overweight or obesity in two independent cohorts of preschool children. J Child Psychol Psychiatry. 2017;58:180-8.

143. Hinney AJ, et al. No evidence for involvement of polymorphisms of the dopamine D4 receptor gene in anorexia nervosa, underweight, and obesity. Am J Med Genet. 1999;88:594-7.

144. Roth CL, Hinney A, Schur EA, Elfers CT, Reinehr T. Association analyses for dopamine receptor gene polymorphisms and weight status in a longitudinal analysis in obese children before and after lifestyle intervention. BMC Pediatr. 2013;13:197.

145. Jozkow P, Slowinska-Lisowska M, Laczmanski L, Medras M. DRD2 C313T and DRD4 48-bp VNTR polymorphisms and physical activity of healthy men in Lower Silesia, Poland (HALS study). Ann Hum Biol. 2013;40:186-90.

146. Sabol SZ, Hu S, Hamer D. A functional polymorphism in the monoamine oxidase A gene promoter. Hum Genet. 1998;103:273-9.

147. Levy ER, Powell JF, Buckle VJ, Hsu YP, Breakefield XO, Craig IW. Localization of human monoamine oxidase-A gene to Xp11.23-11.4 by in situ hybridization: implications for Norrie disease. Genomics. 1989;5:368-70.

148. Huang YY, Cate SP, Battistuzzi C, Oquendo MA, Brent D, Mann JJ. An association between a functional polymorphism in the monoamine oxidase a gene promoter, impulsive traits and early abuse experiences. Neuropsychopharmacology. 2004;29:1498-505.

149. Denney RM, Koch $\mathrm{H}$, Craig IW. Association between monoamine oxidase A activity in human male skin fibroblasts and genotype of the MAOA promoter-associated variable number tandem repeat. Hum Genet. 1999;105: 542-51.

150. Shih JC, Chen K, Ridd MJ. Monoamine oxidase: from genes to behavior. Annu Rev Neurosci. 1999;22:197-217.

151. Need A, Ahmadi K, Spector T, Goldstein D. Obesity is associated with genetic variants that alter dopamine availability. Ann Hum Genet. 2006;70: 293-303.

152. Ducci F, Newman TK, Funt S, Brown GL, Virkkunen M, Goldman D. A functional polymorphism in the MAOA gene promoter (MAOA-LPR) predicts central dopamine function and body mass index. Mol Psychiatry. 2006;11: 858-66

153. Wallmeier $\mathrm{D}$, et al. Genetic modulation of the serotonergic pathway: influence on weight reduction and weight maintenance. Genes Nutr. 2013; 8:601-10.

154. Fuemmeler BF, Agurs-Collins T, Mcclernon FJ, Kollins SH, Garrett ME, AshleyKoch AE. Interactions between genotype and depressive symptoms on obesity. Behav Genet. 2009;39:296-305.
155. Galvão A, Krüger RC, Campagnolo PD, Mattevi VS, Vitolo MR, Almeida S. Association of MAOA and COMT gene polymorphisms with palatable food intake in children. J Nutr Biochem. 2012;23:272-77.

156. Craig SP, Boularand S, Darmon MC, Mallet J, Craig IW. Localization of human tryptophan hydroxylase (TPH) to chromosome 11p15.3-p14 by in situ hybridization. Cytogenet Cell Genet. 1991;56:157-9.

157. Polymeropoulos MH, Xiao H, Rath DS, Merril CR. Tetranucleotide repeat polymorphism at the human tyrosine hydroxylase gene $(\mathrm{TH})$. Nucleic Acids Res. 1991;19:3753.

158. Kobayashi $\mathrm{K}$, et al. Structure of the human tyrosine hydroxylase gene: alternative splicing from a single gene accounts for generation of four mRNA types. J Biochem. 1988;103:907-12.

159. Jönsson $E$, et al. A search for association between schizophrenia and dopamine-related alleles. Eur Arch Psychiatry Clin Neurosci. 1996;246:297-304.

160. Wei J, Ramchand CN, Hemmings GP. Possible association of catecholamine turnover with the polymorphic (TCAT)n repeat in the first intron of the human tyrosine hydroxylase gene. Life Sci. 1997;61:1341-7.

161. Ishiguro $H$, et al. Systematic search for variations in the tyrosine hydroxylase gene and their associations with schizophrenia, affective disorders, and alcoholism. Am J Med Genet. 1998;81:388-96.

162. Persson M, et al. Search for the influence of the tyrosine hydroxylase (TCAT)n repeat polymorphism on personality traits. Psychiatry Res. 2000;95:1-8.

163. Li Y, South T, Han M, Chen J, Wang R, Huang XF. High-fat diet decreases tyrosine hydroxylase mRNA expression irrespective of obesity susceptibility in mice. Brain Res. 2009;1268:181-9.

164. Leite F, Lima M, Marino F, Cosentino M, Ribeiro L. Dopaminergic receptors and tyrosine hydroxylase expression in peripheral blood mononuclear cells: a distinct pattern in central obesity. PLoS One. 2016:11:e0147483.

165. Samuel VT, Shulman Gl. The pathogenesis of insulin resistance: integrating signaling pathways and substrate flux. J Clin Invest. 2016;126:12-22.

166. Junien $C$, van Heyningen $V$. Report of the committee on the genetic constitution of chromosome 11. Cytogenet Cell Genet. 1991;58:459-54.

167. Bell Gl, Horita S, Karam JH. A polymorphic locus near the human insulin gene is associated with insulin-dependent diabetes mellitus. Diabetes. 1984; 33:176-83.

168. Bennett ST, et al. IDDM2-VNTR-encoded susceptibility to type 1 diabetes: dominant protection and parental transmission of alleles of the insulin gene-linked minisatellite locus. J Autoimmun. 1996:9:415-21.

169. Bennett ST, Todd JA. Human type 1 diabetes and the insulin gene: principles of mapping polygenes. Annu Rev Genet. 1996;30:343-70.

170. Kennedy GC, German MS, Rutter WJ. The minisatellite in the diabetes susceptibility locus IDDM2 regulates insulin transcription. Nat Genet. 1995; 9:293-8.

171. Le Stunff C, Fallin D, Schork NJ, Bougneres P. The insulin gene VNTR is associated with fasting insulin levels and development of juvenile obesity. Nat Genet. 2000;26:444-6.

172. Todd JA, et al. Robust associations of four new chromosome regions from genome-wide analyses of type 1 diabetes. Nat Genet. 2007;39:857-64

173. Ong KK, et al. The insulin gene VNTR, type 2 diabetes and birth weight. Nat Genet. 1999;21:262-3.

174. Eriksson JG, Osmond C, Forsénc J, Kajantie E, Barker JP, Laakso M. Insulin gene variable number of tandem repeat genotype, early growth and glucose metabolism in adult life. Int J Endocrinol Metab. 2006;4:180-7.

175. Bazaes RA, Petry CJ, Ong KK, Avila A, Dunger DB, Mericq MV. Insulin gene VNTR genotype is associated with insulin sensitivity and secretion in infancy. Clin Endocrinol (Oxf). 2003;59:599-603.

176. Huxtable SJ, et al. Analysis of parent-offspring trios provides evidence for linkage and association between the insulin gene and type 2 diabetes mediated exclusively through paternally transmitted class III variable number tandem repeat alleles. Diabetes. 2000:49:126-30.

177. Mitchell SM, et al. Lack of support for a role of the insulin gene variable number of tandem repeats minisatellite (INS-VNTR) locus in fetal growth or type 2 diabetes-related intermediate traits in United Kingdom populations. J Clin Endocrinol Metab. 2004:89:310-7.

178. Vu-Hong TA, et al. The INS VNTR locus does not associate with smallness for gestational age (SGA) but interacts with SGA to increase insulin resistance in young adults. J Clin Endocrinol Metab. 2006:91:2437-40.

179. Lindsay RS, Hanson RL, Wiedrich C, et al. The insulin gene variable number tandem repeat class $1 /$ III polymorphism is in linkage disequilibrium with birth weight but not type 2 diabetes in the Pima population. Diabetes. 2003:52:187-93. 
180. Bennett AJ, et al. Variation at the insulin gene VNTR (variable number tandem repeat) polymorphism and early growth: studies in a large Finnish birth cohort. Diabetes. 2004;53:2126-31.

181. Hansen SK, et al. Large-scale studies of the Hphl insulin gene variablenumber-of-tandem-repeats polymorphism in relation to type 2 diabetes mellitus and insulin release. Diabetologia. 2004;47:1079-87.

182. Meigs JB, et al. The insulin gene variable number tandem repeat and risk of type 2 diabetes in a population based sample of families and unrelated men and women. J Clin Endocrinol Metab. 2005;90:1137-43.

183. Le Stunff $C$, Fallin $D$, Bougnères $P$. Paternal transmission of the very common class I INS VNTR alleles predisposes to childhood obesity. Nat Genet. 2001;29:96-9.

184. Heude B, et al. VNTR polymorphism of the insulin gene and childhood overweight in a general population. Obes Res. 2004;12:499-504.

185. Heude $B$, et al. The insulin gene variable number of tandem repeat: associations and interactions with childhood body fat mass and insulin secretion in normal children. J Clin Endocrinol Metab. 2006;91:2770-5.

186. Santoro N, et al. Insulin gene variable number of tandem repeats (INS VNTR) genotype and metabolic syndrome in childhood obesity. J Clin Endocrinol Metab. 2006;91:4641-4.

187. Maas JA, et al. Insulin VNTR and IGF-1 promoter region polymorphisms are not associated with body composition in early childhood: the generation $\mathrm{R}$ study. Horm Res Paediatr. 2010;73:120-7.

188. Sandhu MS, et al. INS VNTR class genotype and indexes of body size and obesity: population-based studies of 7,999 middle-aged men and women. Diabetes. 2005;54:2812-5.

189. Bougnères P. Editorial: genotypic and phenotypic complexity at the insulin variable number of tandem repeats locus. J Clin Endocrinol Metab. 2006;91: 4246-9.

190. Eaves IA, et al. Transmission ratio distortion at the INS-IGF2 VNTR. Nat Genet. 1999:22:324-5.

191. Bouatia-Naji N, et al. INS VNTR is not associated with childhood obesity in 1,023 families: a family-based study. Obesity (Silver Spring). 2008;16:1471-5

192. Perrier S, Darakhshan F, Hajduch E. IL-1 receptor antagonist in metabolic diseases: Dr Jekyll or Mr Hyde? FEBS Lett. 2006;580:6289-94.

193. Juge-Aubry CE, et al. Adipose tissue is a major source of interleukin-1 receptor antagonist: upregulation in obesity and inflammation. Diabetes. 2003;52:1104-10.

194. Somm E, et al. Decreased fat mass in interleukin-1 receptor antagonistdeficient mice: impact on adipogenesis, food intake, and energy expenditure. Diabetes. 2005;54:3503-9.

195. Meier CA, Bobbioni E, Gabay C, Assimacopoulos-Jeannet F, Golay A, Dayer JM. IL-1 receptor antagonist serum levels are increased in human obesity: a possible link to the resistance to leptin? J Clin Endocrinol Metab. 2002;87: 1184-8.

196. Vamvakopoulos JE, Taylor CJ, Morris-Stiff GJ, Green C, Metcalfe S. The interleukin-1 receptor antagonist gene: a single-copy variant of the intron 2 variable number tandem repeat (VNTR) polymorphism. Eur J Immunogenet. 2002;29:337-40.

197. Tarlow JK, et al. Polymorphism in human IL-1 receptor antagonist gene intron 2 is caused by variable numbers of an $86-b p$ tandem repeat. Hum Genet. 1993;91:403-4.

198. Witkin SS, Gerber S, Ledger WJ. Influence of interleukin-1 receptor antagonist gene polymorphism on disease. Clin Infect Dis. 2002;34:204-9.

199. Hurme M, Santtila S. IL-1 receptor antagonist (IL-1Ra) plasma levels are coordinately regulated by both IL-1Ra and IL-1beta genes. Eur J Immunol. 1998;28:2598-602.

200. Um JY, Kim HM, Mun SW, Song YS, Hong SH. Interleukin-1 receptor antagonist gene polymorphism and traditional classification in obese women. Int J Neurosci. 2006;116(1):39-53.

201. Manchanda PK, Bid HK, Achyut BR, Mittal B, Srivastava N, Mittal RD. Interleukin-1 receptor antagonist gene polymorphism and obesity: a pilot study from north India. Indian J Clin Biochem. 2007;22(1):61-4.

202. Kok $Y$ Y, Ong HH, Say $Y H$. Interleukin-1 receptor antagonist and interleukin-4 genes variable number tandem repeats are associated with adiposity in Malaysian subjects. J Obes. 2017;2017:4104137.

203. Nelms K, Keegan AD, Zamorano J, Ryan JJ, Paul WE. The IL-4 receptor: signaling mechanisms and biologic functions. Annu Rev Immunol. 1999;17: 701-38.

204. Mito N, Hosoda T, Kato C, Sato K. Change of cytokine balance in dietinduced obese mice. Metabolism. 2000;49:1295-300.
205. Chang YH, Ho KT, Lu SH, Huang CN, Shiau MY. Regulation of glucose/lipid metabolism and insulin sensitivity by interleukin-4. Int J Obes (Lond). 2012; 36:993-8.

206. Borst SE, Conover CF, Bagby GJ. Association of resistin with visceral fat and muscle insulin resistance. Cytokine. 2005;32:39-44.

207. Tsao CH, Shiau MY, Chuang PH, Chang YH, Hwang J. Interleukin-4 regulates lipid metabolism by inhibiting adipogenesis and promoting lipolysis. J Lipid Res. 2014;55:385-97.

208. Rao RR, et al. Meteorin-like is a hormone that regulates immune-adipose interactions to increase beige fat thermogenesis. Cell. 2014;157:1279-91.

209. Mout R, Willemze R, Landegent JE. Repeat polymorphisms in the interleukin-4 gene (IL4). Nucleic Acids Res. 1991;19:3763.

210. Inanir A, et al. Association of IL-4 gene VNTR variant with deep venous thrombosis in Behçet's disease and its effect on ocular involvement. Mol Vision. 2013;19:675-83.

211. Nakashima $H$, et al. Association between IL-4 genotype and IL-4 production in the Japanese population. Genes Immunity. 2002;3:107-9.

212. Olsson T. Cytokine-producing cells in experimental autoimmune encephalomyelitis and multiple sclerosis. Neurology. 1995:45:S11-5.

213. Buchs N, et al. IL-4 VNTR gene polymorphism in chronic polyarthritis. The rare allele is associated with protection against destruction. Rheumatology. 2000;39:1126-31.

214. Wu MC, Huang CM, Tsai JJ, Chen HY, Tsai FJ. Polymorphisms of the interleukin-4 gene in Chinese patients with systemic lupus erythematosus in Taiwan. Lupus. 2003;12:21-5.

215. Sobti RC, Maithil N, Thakur H, Sharma Y, Talwar KK. VEGF and IL-4 gene variability and its association with the risk of coronary heart disease in north Indian population. Mol Cell Biochem. 2010;341:139-48.

216. Tekcan A, Yigit S, Rustemoglu A, Gurel C, Sahin S, Tasliyurt T. The investigation of obesity susceptibility with IL-4 gene intron 3 VNTR and IL-6 gene -597G/A polymorphisms in a Turkish population. Int J Human Genet. 2013;13:209-13.

217. Bid HK, Konwar R, Agrawal CG, Banerjee M. Association of IL-4 and IL-1RN (receptor antagonist) gene variants and the risk of type 2 diabetes mellitus: a study in the north Indian population. Indian J Med Sci. 2008;62:259-66.

218. Nathan C, Xie QW. Nitric oxide synthases: roles, tolls, and controls. Cell. $1994 ; 78: 915-8$.

219. Heinonen l, et al. Effect of nitric oxide synthase inhibition on the exchange of glucose and fatty acids in human skeletal muscle. Nutr Metab. 2013;10:43-50.

220. Perez-Matute P, Neville MJ, Tan GD, Frayn KN, Karpe F. Transcriptional control of human adipose tissue blood flow. Obesity (Silver Spring). 2009;17:681-8.

221. Georgescu A, et al. Dysfunction of human subcutaneous fat arterioles in obesity alone or obesity associated with type 2 diabetes. Clin Sci (Lond). 2011;120:463-72.

222. Valerio A, et al. TNF-alpha downregulates eNOS expression and mitochondrial biogenesis in fat and muscle of obese rodents. J Clin Invest 2006:116:2791-8.

223. Wang Y, Kikuchi S, Suzuki H, Nagase S, Koyama A. Endothelial nitric oxide synthase gene polymorphism in intron 4 affects the progression of renal failure in non diabetic renal disease. Nephrol Dialysis Transplant. 1999;14: 2898-902.

224. Wang XL, et al. Genetic contribution of the endothelial constitutive nitric oxide synthase gene to plasma nitric oxide levels. Arterioscler Thromb Vasc Biol. 1997; 17:3147-53.

225. AlFadhli S. Influence of endothelial nitric oxide synthase gene intron-4 $27 \mathrm{bp}$ repeat polymorphism on its expression in autoimmune diseases. Dis Markers. 2013;34:349-56.

226. Wang J, Dudley D, Wang XL. Haplotype-specific effects on endothelial NO synthase promoter efficiency: modifiable by cigarette smoking. Arterioscler Thromb Vasc Biol. 2002;22:e1-4.

227. Zhang MX, et al. Regulation of endothelial nitric oxide synthase by small RNA. Proc Natl Acad Sci U S A. 2005:102:16967-72.

228. Zhang $M X$, et al. Effect of 27 nt small RNA on endothelial nitric oxide synthase expression. Mol Biol Cell. 2008;19:3997-4005.

229. Marra M, Scalfi L, Contaldo F, Pasanisi F. Fasting respiratory quotient as a predictor of long-term weight changes in non-obese women. Ann Nutr Metab. 2004;48:189-92.

230. Nasr HB, et al. Functional G894T (rs1799983) polymorphism and intron-4 VNTR variant of nitric oxide synthase (NOS3) gene are susceptibility biomarkers of obesity among Tunisians. Obes Res Clin Pract. 2016;10: $465-75$. 
231. Monti LD, et al. Endothelial nitric oxide synthase polymorphisms are associated with type 2 diabetes and the insulin resistance syndrome. Diabetes. 2003;52:1270-5.

232. Ohtoshi $\mathrm{K}$, et al. Association of (-)786T-C mutation of endothelial nitric oxide synthase gene with insulin resistance. Diabetologia. 2002;45:1594-601.

233. Yoshimura $T$, et al. The relationship between insulin resistance and polymorphisms of the endothelial nitric oxide synthase gene in patients with coronary artery disease. J Atheroscler Thromb. 2003;10:43-7.

234. Vecoli C, et al. T(-786) $\rightarrow$ C polymorphism of the endothelial nitric oxide synthase gene is associated with insulin resistance in patients with ischemic or non ischemic cardiomyopathy. BMC Med Genet. 2012;13:92.

235. Gonzalez-Sanchez JL, Martinez-Larrad MT, Saez ME, Zabena C, MartinezCalatrava MJ, Serrano-Rios M. Endothelial nitric oxide synthase haplotypes are associated with features of metabolic syndrome. Clin Chem. 2007;53:91-7.

236. Rittig K, et al. Endothelial NO-synthase intron 4 polymorphism is associated with disturbed in vivo nitric oxide production in individuals prone to type 2 diabetes. Horm Metab Res. 2008;40:13-7.

237. Zeljko HM, et al. E2 allele of the apolipoprotein E gene polymorphism is predictive for obesity status in Roma minority population of Croatia. Lipids Health Dis. 2011;10:9.

238. Fyhrquist F, Saijonmaa O. Renin-angiotensin system revisited. J Intern Med. 2008;264:224-36.

239. Jones BH, Standridge MK, Moustaid N. Angiotensin II increases lipogenesis in 3T3-L1 and human adipose cells. Endocrinology. 1997;138:1512-9.

240. Slamkova M, Zorad S, Krskova K. Alternative renin-angiotensin system pathways in adipose tissue and their role in the pathogenesis of obesity. Endocr Regul. 2016;50:229-40.

241. Rigat B, Hubert C, Alhenc-Gelas F, Cambien F, Corvol P, Soubrier F. An insertion/deletion polymorphism in the angiotensin l-converting enzyme gene accounting for half the variance of serum enzyme levels. J Clin Invest. 1990;86:1343-6.

242. Gard PR. Implications of the angiotensin converting enzyme gene insertion/ deletion polymorphism in health and disease: a snapshot review. Int J Mol Epidemiol Genet. 2010;1:145-57.

243. Li Y. Angiotensin-converting enzyme gene insertion/deletion polymorphism and essential hypertension in the Chinese population: a meta-analysis including 21,058 participants. Intern Med J. 2012;42:439-44.

244. Samani NJ, Thompson JR, O'Toole L, Channer K, Woods KL. A meta-analysis of the association of the deletion allele of the angiotensin-converting enzyme gene with myocardial infarction. Circulation. 1996;94:708-12.

245. Luo R, et al. The influence of angiotensin converting enzyme and angiotensinogen gene polymorphisms on hypertrophic cardiomyopathy. PLoS One. 2013;8(10):e77030.

246. Xi B, Ruiter R, Chen J, Pan H, Wang Y, Mi J. The ACE insertion/deletion polymorphism and its association with metabolic syndrome. Metabolism. 2012;61:891-7.

247. Niu W, Qi Y, Gao P, Zhu D. Angiotensin converting enzyme D allele is associated with an increased risk of type 2 diabetes: evidence from a metaanalysis. Endocr J. 2010;57:431-8.

248. You CH, et al. The relationship between ACE I/D polymorphism and HDL cholesterol. J Prev Med Public Health. 2006;39:505-10.

249. Strazzullo P, et al. Genetic variation in the renin-angiotensin system and abdominal adiposity in men: the Olivetti Prospective Heart Study. Ann Intern Med. 2003;138(1):17-23.

250. Riera-Fortuny $C$, et al. The relation between obesity, abdominal fat deposit and the angiotensin-converting enzyme gene I/D polymorphism and its association with coronary heart disease. Int J Obes (Lond). 2005;29:78-84.

251. El-Hazmi MA, Warsy AS. Increased frequency of angiotensin-converting enzyme DD genotype in Saudi overweight and obese patients. Ann Saudi Med. 2003;23:24-7.

252. Akin F, et al. Angiotensin-converting enzyme gene polymorphism in overweight and obese Turkish patients with insulin resistance. DNA Cell Biol. 2010;29:207-12

253. Lemes VA, et al. Angiotensin converting enzyme insertion/deletion polymorphism is associated with increased adiposity and blood pressure in obese children and adolescents. Gene. 2013;532:197-202.

254. Ponsonby AL, et al. Adiposity gain during childhood, ACE I/D polymorphisms and metabolic outcomes. Obesity (Silver Spring). 2008;16:2141-7.
255. Bienertova-Vasku J, et al. Effect of ID ACE gene polymorphism on dietary composition and obesity-related anthropometric parameters in the Czech adult population. Genes Nutr. 2009:4:207-13.

256. Shunmugam V, Say YH. Evaluation of association of ADRA2A rs553668 and ACE I/D gene polymorphisms with obesity traits in the Setapak population, Malaysia. Iran Red Crescent Med J. 2016;18:e22452.

257. Ryan AS, Nicklas BJ, Berman DM, Ferrell RE. The insertion/deletion polymorphism of the ACE gene is related to insulin sensitivity in overweight women. Diabetes Care. 2001;24:1646-52.

258. Um JY, et al. Polymorphism of angiotensin-converting enzyme gene and BMI in obese Korean women. Clin Chim Acta. 2003;328:173-8.

259. Kim K. Association of angiotensin-converting enzyme insertion/deletion polymorphism with obesity, cardiovascular risk factors and exercisemediated changes in Korean women. Eur J Appl Physiol. 2009;105:879-87.

260. Pan $\mathrm{YH}$, et al. ACE gene I/D polymorphism and obesity in 1,574 patients with type 2 diabetes mellitus. Dis Markers. 2016;2016:7420540.

261. El-Sayed Moustafa JS, et al. Novel association approach for variable number tandem repeats (VNTRs) identifies DOCK5 as a susceptibility gene for severe obesity. Hum Mol Genet. 2012;21:3727-38.

262. Jenkins A, Archer SN, von Schantz M. Expansion during primate radiation of a variable number tandem repeat in the coding region of the circadian clock gene period3. J Biol Rhythm. 2005;20:470-2.

263. Ebisawa $T$, et al. Association of structural polymorphisms in the human period3 gene with delayed sleep phase syndrome. EMBO Rep. 2001;2:342-6.

264. Ellis J, von Schantz M, Jones KH, Archer SN. Association between specific diurnal preference questionnaire items and PER3 VNTR genotype. Chronobiol Int. 2009;26:464-73.

265. Bienertova-Vaskua J, et al. The PER3 VNTR polymorphism is a predictor of dietary composition in the Central European population. Biol Rhythm Res. 2014;45:747-57.

266. Gallo V, et al. STrengthening the Reporting of OBservational studies in Epidemiology - Molecular Epidemiology (STROBE-ME): an extension of the STROBE statement. PLoS Med. 2011;8:e1001117.

267. 1000 Genomes Project Consortium. A global reference for human genetic variation. Nature. 2015:526:68-74.

\section{Submit your next manuscript to BioMed Central and we will help you at every step:}

- We accept pre-submission inquiries

- Our selector tool helps you to find the most relevant journal

- We provide round the clock customer support

- Convenient online submission

- Thorough peer review

- Inclusion in PubMed and all major indexing services

- Maximum visibility for your research

Submit your manuscript at www.biomedcentral.com/submit

) Biomed Central 